\title{
Prediction of side effects from anticancer treatment with the purpose to increase quality of life
}

\section{Delmy Oliva}
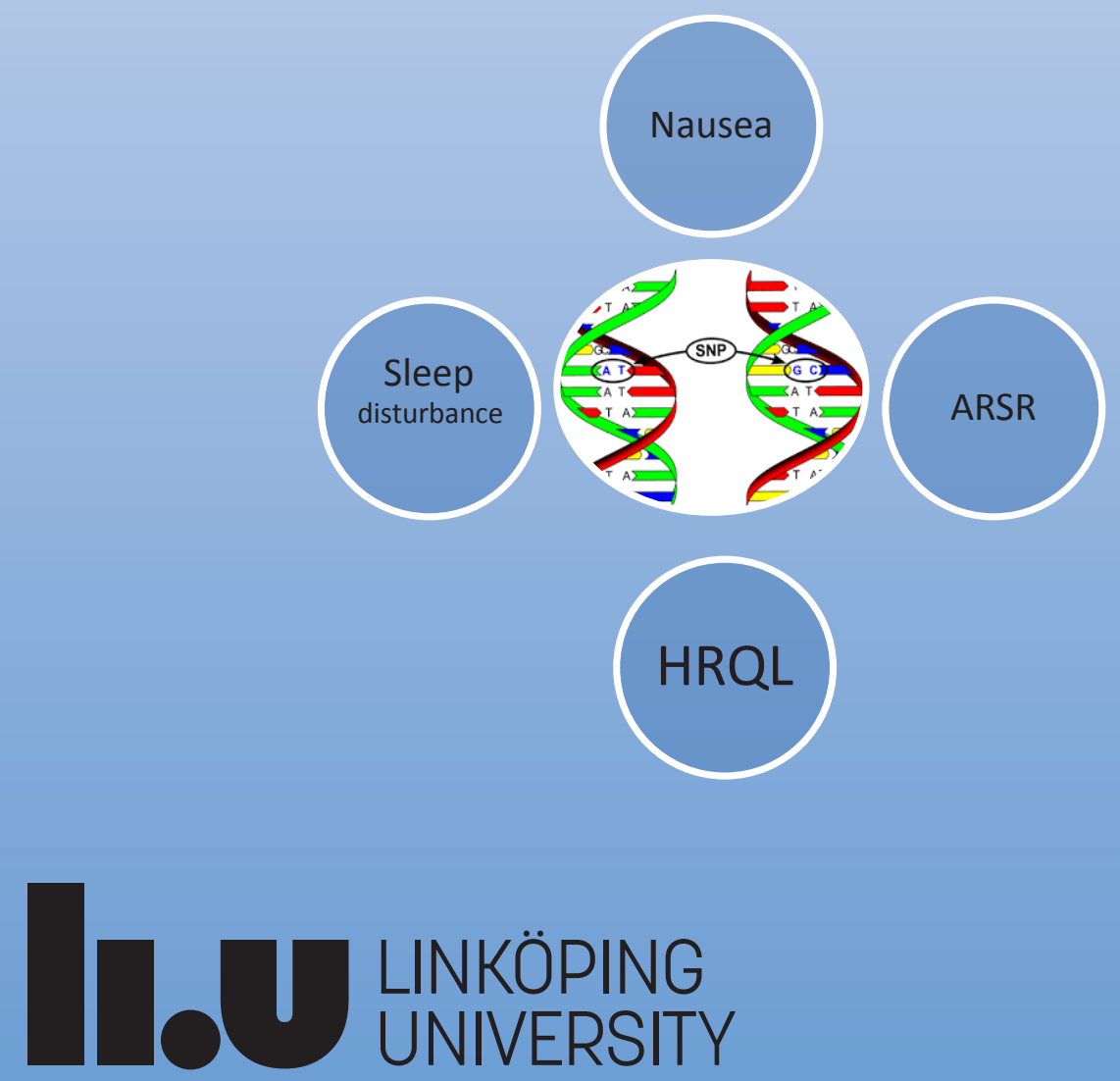

\section{LINKÖPING UNIVERSITY}


Linköping University Medical Dissertation No. 1716

Prediction of side effects from anticancer treatment with the purpose of increasing quality of life

\author{
Delmy Oliva
}



\author{
Department of Oncology \\ Jönköping County
}

Institutionen för klinisk och experimentell medicin

Department of Medical and Health Sciences

Linköping University, Sweden

Linköping 2019 
(C) Delmy Oliva. 2019

Published articles, surveys and figures have been reprinted with the permission of the copyright holder.

Printed in Sweden by LiU-tryck, 2019

ISBN 978-91-7929-956-9

ISSN 0345-0082 


\title{
Prediction of side effects from anticancer treatment with the purpose of increasing quality of life
}

\author{
THESIS FOR DOCTORAL DEGREE (PH.D.) \\ By
}

\section{Delmy Oliva}

\section{Principal supervisor:}

Associate professor Freddi Lewin, MD. Department of Oncology, County Hospital Ryhov, Jönköping, Sweden and Institution for Clinical and Experimental Medicine, Linköping University, Linköping, Sweden.

\section{Co supervisors:}

Professor Charlota Dabrosin, MD. Institution for Clinical and Experimental Medicine, Linköping University, Linköping, Sweden.

Lena Sharp, RN, PhD. Regional Cancer Centre, Stockholm-Gotland, Stockholm, Sweden and Department of Learning, Informatics, Management and Ethics, Division of Innovative Care Research, Karolinska Institute,Stockholm, Sweden

Associate professor Lasse Jensen, PhD. Department of Medical and Health Sciences, Linköping University, Linköping, Sweden.

\section{Opponent:}

Associate professor Eva Brun, MD. PhD. Department of Oncology and Pathology, Lund University, Lund, Sweden

\section{Examination board:}

Associate professor Jan Erik Karlsson, Department of Medicine and Health, Linköping University, Linköping, Sweden. Chairman of the board.

Associate professor Mikael Johansson, Department of Radiotherapy, Umeå University, Umeå, Sweden

Associate professor Thomas Walz, Institution for clinical and Experimental Medicine, Linköping University, Linköping, Sweden. 
"Para la familia aqui y donde se encuentren" "To my family here and wherever they are" 


\begin{abstract}
Cancer and its treatments can cause a variety of symptoms. Some of these symptoms are related to the disease and others are seen as a consequence of the treatment. Since patients experience side effects to different degrees despite undergoing the same treatment, it is hypothesized that there is a genetic factor. The individual variation that exists between different patients regarding nausea triggered by chemotherapy, radiotherapy induced skin reactions as well as sleep disorders associated with cancer could partly be explained by genetic differences. We have in these studies confirmed these individual differences. Previous nursing research has mainly focused on the symptoms themselves. The focus in this thesis are the following three main symptoms; nausea and vomiting related to chemotherapy, acute skin inflammation following radiotherapy and sleep problems associated with cancer diagnosis and -treatment.
\end{abstract}

The aim of this thesis was to find biological markers that can identify the risk of and/or protective factors for nausea and/or vomiting (CINV) as well as understand its heterogeneity (Study 1 and 2). It also aimed to understand the individual factors behind acute radiation skin reactions (ARSR) (Study 3 ) and sleeping disturbances in patients treated for cancer (Study 4), permitting a more individualized care and optimized health-related quality of life (HRQoL).

In Study 1 and 2 the patients themselves had to document in a diary their experience of nausea and vomiting and well-being. Well-being was considered as synonymous with quality of life. We found a variability and heterogeneity of those symptoms (Study 1). Three genetic markers, FAS/CD95, RB1/LPAR6 and CCL2 that could explain the individual 
differences and assess the risk of chemotherapy-induced nausea were found in Study 2.

Acute radiation skin reactions (ARSR) along with itching and burning sensation associated with radiotherapy (RT) was assessed by the patients themselves (Study 3) with help of the VAS- and RTOG scales, scoring for visible redness. We found two possible genetic markers, XRCC2 and IFNG. Also, individual differences in symptoms behavior were found.

Sleep disturbances were common and were reported with obvious individual differences [1]. For data collection were used a sleep questionnaire, the Medical Outcomes Study Sleep Scale (MOS), open ended questions and EORTC QLQ- C30 questionnaire of quality of life. Sleep, which is important for all primary body functions, is often affected in connection with cancer diagnosis and -treatment.

Through collaboration between nursing staff and specialists in basic science, we have found that biological markers can help in creating individualized care. Knowledge of individual variations in the severity of chemo- or radiotherapy-induced side effects is important in order to better personalize the treatment and care, improve the treatment results and alleviate or prevent the side effects of oncological treatments. By linking symptoms to biological markers, it will hopefully be able to increase the patients' total health-related quality of life, this being the main goal of this thesis. 


\section{Sammanfattning på svenska}

Cancer och dess behandlingar kan orsaka en mängd olika symtom. Några av dessa symtom är relaterade till sjukdomen och andra bedöms vara en följd av behandlingen. Patienter upplever olika grader av biverkningar i samband med cancerbehandling. De individuella variationer som finns mellan olika patienter med avseende på illamående som orsakas av cytostatikabehandling, akuta hudreaktioner vid strålbehandlingen och sömnstörningar i samband med cancerbehandling kan delvis förklaras av genetiska skillnader. Vi har i dessa studier bekräftat dessa individuella skillnader. Tidigare omvårdnadsforskning har i huvudsak fokuserat på symtomen i sig. I denna avhandling är följande tre huvudsymptom i fokus: illamående och kräkningar i samband med cytostatikabehandling, akut hudinflammation efter strålbehandling och sömnproblem i samband med diagnos och behandling.

Syftet var att hitta biologiska markörer som kan identifiera risk för eller skyddande faktorer för illamående och/eller kräkningar (CINV) som uppstår på grund av cytostatikabehandling och förstå dess heterogenitet (studierna 1 och 2). Och att bättre förstå de enskilda faktorerna bakom akuta hudreaktioner från strålbehandling (ARSR) (Studie 3) och sömnstörningar hos patienter som behandlats för cancer (Studie 4).

I studierna 1 och 2 fick patienterna själva dokumentera sin erfarenhet av illamående och kräkningar och välbefinnande i en dagbok. Välbefinnande betraktades som synonymt med livskvaliteten. Vi hittade en variabilitet mellan patienterna (Studie 1). Tre genetiska markörer i generna FAS/CD95, RB1/LPAR6 och CCL2 identifierades som kan förklara skillnaderna i 
upplevelse mellan patienterna och utvärdera risken för cytostatika inducerat illamående (studie 2).

Akuta hudreaktioner vid strålbehandling hopräknat med klåda och brännande känsla i samband med strålbehandling självrapporterades av patienterna (studie 3) med hjälp av VAS-skala och RTOG-skala för synlig rodnad. Vi fann att patienterna drabbades individuellt olika. Två möjliga genetiska markörer i generna XRCC2 och IFNG relaterade till risken att uppleva dessa biverkningar identifierades.

Sömnstörningar var vanliga och rapporterades med uppenbara individuella skillnader [2]. För datainsamling användes en sömnenkät, The Medical Outcomes Study Sleep Scale, öppna frågor och EORTC QLQ- C30 frågeformulär för livskvalitet. Sömn, som är viktigt för alla kroppsfunktioner, påverkas ofta i samband med cancerdiagnos och behandling.

Genom samarbete mellan vårdpersonal och biologiska specialister har vi funnit biologiska markörer som förhoppningsvist kan hjälpa till i utvecklingen med att individualisera vården. Kunskap om individuell variation i svårighetsgraden av cytostatika- eller strålbehandling inducerade biverkningar är viktig att förstå för att bättre kunna anpassa omvårdnad och behandling. Denna kunskap möjliggör på sikt en mer individualiserad vård och optimerad hälsorelaterad livskvalitet [3] vilket är huvudmålet för avhandlingen. 


\section{List of publications}

The thesis is based on the following publications and manuscript, referred to in roman numerals in the text

I. Oliva, D., et al., Variations in self-reported nausea, vomiting, and wellbeing during the first 10 days postchemotherapy in women with breast cancer. Clin J Oncol Nurs, 2014. 18(2): p. E32-6.

II. Oliva, D., et al., Single nucleotide polymorphisms might influence chemotherapy induced nausea in women with breast cancer. Clinical and Translational Radiation Oncology, 2017. 2: p. 1-6.

III. Oliva, D., et al., Individual Genetic Variation Might Predict Acute Skin Reactions in Women Undergoing Adjuvant Breast Cancer Radiotherapy. Anticancer Res, 2018. 38(12): p. 6763-6770.

IV. Oliva, D. Jensen, L. Sharp, L. Nilsson, M. Lewin, F., Sleep

Disturbance after Cancer Diagnosis and Treatment- A multifaceted

Clinical Problem- A pilot study.

Manuscript.

"The manuscript was incorrectly published in J Neurol Neurosci, 2019. 10: pp. 1-8. The journal is not considered scientific" 


\section{Abbreviations}

\begin{tabular}{|c|c|}
\hline ABCA1 & ATP-binding cassette transporter A member1 \\
\hline ANV & Anticipatory Nausea and Vomiting \\
\hline ARSR & Acute Radiation Skin Reactions \\
\hline ATM & Ataxia telangiectasia mutated \\
\hline $\mathrm{BC}$ & Breast cancer \\
\hline BRCA1 & Breast cancer 1 \\
\hline BRCA2 & Breast cancer 2 \\
\hline Casp 8 & Caspase 8, apoptosis-related cysteine peptidase \\
\hline Casp 9 & Caspase 9 , apoptosis-related cysteine peptidase \\
\hline CCL2 & Chemokine (C-C motif) ligand 2 \\
\hline CCL4 & Chemokine (C-C motif) ligand 4 \\
\hline CCL5/RANTES & Chemokine (C-C motif) ligand 5 \\
\hline CCND3 & Cyclin D3 \\
\hline CDKN2A & Cyclin-dependent kinase inhibitor 2A \\
\hline CI & Confidence interval \\
\hline CINV & Chemotherapy Induced Nausea and Vomiting \\
\hline CRP & C-reactive protein \\
\hline $\mathrm{CRF}$ & Case Report Form \\
\hline Cyp2D6 & Cytochrome P450, family 2, subfamily D, polypeptide 6 \\
\hline Cyp19A1 & Cytochrome P450, Family 19, Subfamily A, Polypeptide 1 \\
\hline DNA & Deoxyribonucleic acid \\
\hline DNAPK & DNA-activated protein kinase \\
\hline $\mathrm{EC}$ & Epirubicin+ Cyclophosphamide \\
\hline ECOG & $\begin{array}{l}\text { Toxicity and Response Criteria of the Eastern Cooperative } \\
\text { Oncology Group }\end{array}$ \\
\hline EDTA & Ethylene diamine tetra acetic acid \\
\hline EGF & Epidermal growth factor \\
\hline EGFR & Epidermal growth factor receptor \\
\hline EORTC & The European Organization for Research and Treatment of Cancer \\
\hline Estrogen $\mathrm{R}$ & Estrogen receptor \\
\hline FAS & Apoptosis-mediating Surface antigen FAS (CD antigen CD95) \\
\hline FEC & Fluorouracil+ Epirubicin+ Cyclophosphamide \\
\hline
\end{tabular}




\begin{tabular}{|c|c|}
\hline FGFR2 & Fibroblast growth factor receptor 2 \\
\hline FGFR4 & Fibroblast Growth Factor Receptor 4 \\
\hline $5-\mathrm{FU}$ & Fluorouracil \\
\hline GASC1 & Gene amplified in squamous cell carcinoma 1 protein \\
\hline GCSF & Granulocyte colony stimulating factor \\
\hline GSPTP1 & Glutathione S-transferase gene class P1 \\
\hline GZB & Granzyme B (natural killer cell protease) \\
\hline HER-2 & Human Epidermal Growth Factor Receptor 2 \\
\hline HRQoL & Health Related Quality of Life \\
\hline IFNg & Interferon, gamma, Cytokine \\
\hline IL2 & Interleukin 2 \\
\hline IL6 & Interleukin 6 \\
\hline IL12RB & Interleukin 12 receptor, beta 1 \\
\hline $\mathrm{Ku} 70$ & ATP-dependent DNA helicase 2 subunit KU70 \\
\hline MDR & Multidrug resistance protein 1 \\
\hline MCP1(CCL2) & Monocyte Chemoattractant Protein-1 (MCP-1) \\
\hline MMP2 & Matrix metalloproteinase-2 \\
\hline MOS & Medical Outcomes Study Sleep Scale \\
\hline mRNA & Messenger- RNA \\
\hline MRP5 & Multidrug resistance-associated protein 5 \\
\hline MTHFR & Methylenetetrahydrofolate reductase \\
\hline OR & Odds ratio \\
\hline P16 & Cyclin-dependent kinase inhibitor 2A, multiple tumor suppressor 1 \\
\hline P53 & Cellular tumor antigen p53 (tumor suppressor p53) \\
\hline Porferin1 & Perforin 1 (lymphocyte pore-forming protein) \\
\hline PS & Performance Status \\
\hline PUL & Personal Data Act \\
\hline QLQ-C 30 & The EORTC core quality of life questionnaire \\
\hline QoL & Quality of life \\
\hline RT & Radiotherapy \\
\hline RTOG & Radiation Therapy Oncology Group \\
\hline Rad52 & DNA repair protein RAD52 homolog \\
\hline $\mathrm{Rb} 1$ & Retinoblastoma-associated protein \\
\hline SNP & Single Nucleotide Polymorphism \\
\hline TNF $\alpha$ & Tumour necrosis factor- $\alpha$ \\
\hline
\end{tabular}




\begin{tabular}{ll}
\hline TNM & Tumour, node, metastasis \\
\hline VAS & Visual Analogue Scale \\
\hline WHO & World Health Organization \\
\hline XRCC1 & X-ray repair cross complementing protein 1 \\
\hline XRCC2 & X-ray repair cross complementing protein 2 \\
\hline XRCC3 & X-ray repair cross complementing protein 3 \\
\hline
\end{tabular}




\section{Contents}

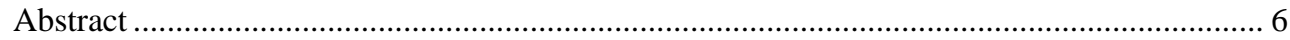

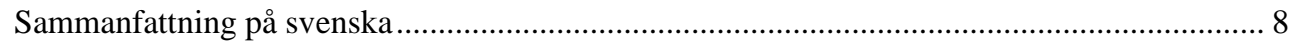

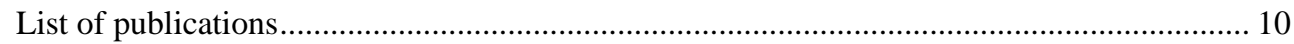



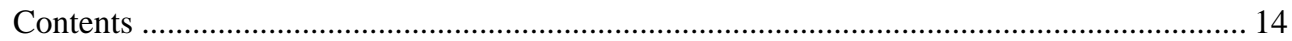



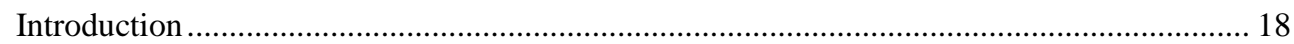





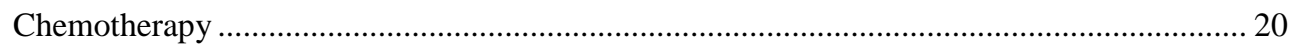

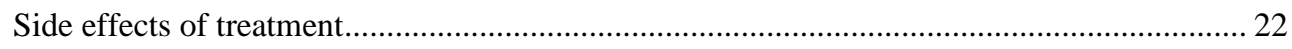

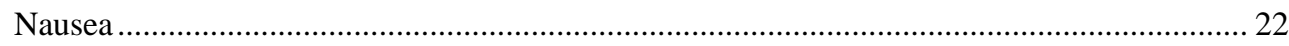

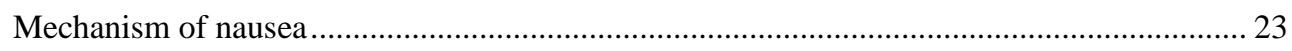

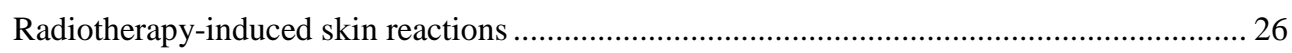

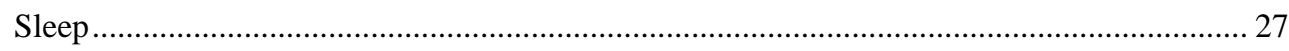

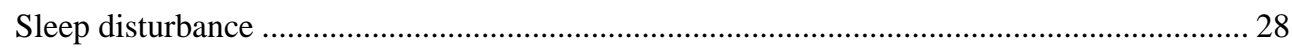



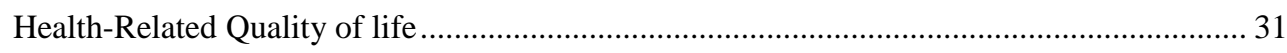



Single Nucleotide Polymorphism definition and application on the clinical





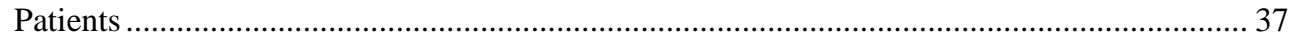





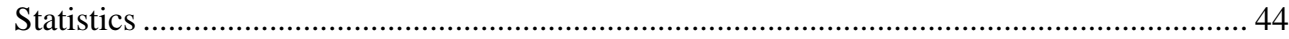




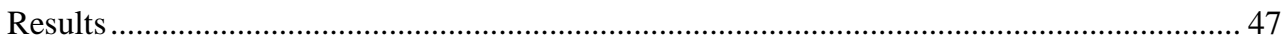





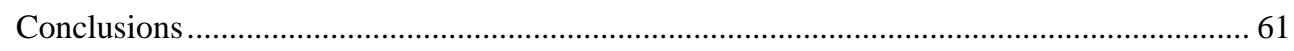

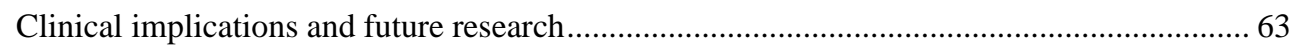

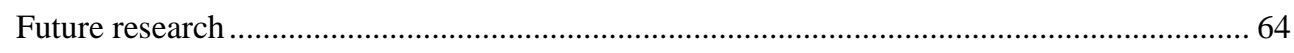



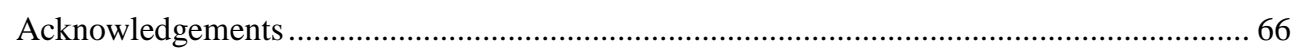

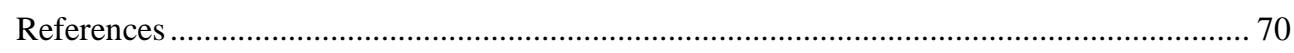



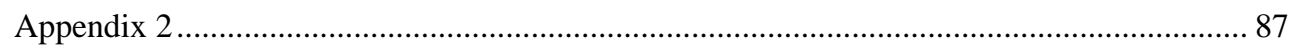

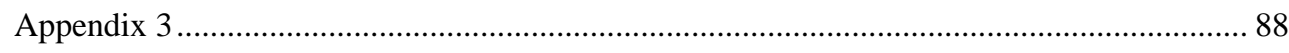

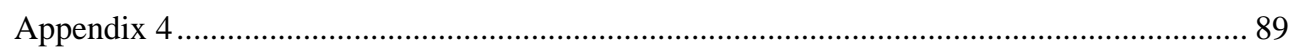

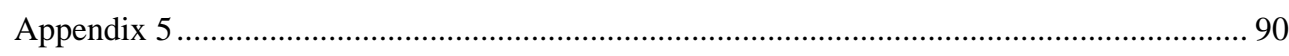

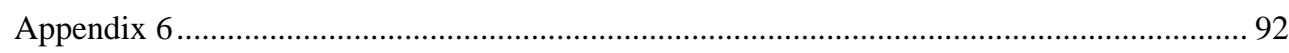




\section{Preface}

I started my nursing studies in 1994, four years after I arrived in Sweden. I already had three years of education in psychology. So, why study to be a nurse? It was an easy decision since I wanted to work with people. I could not speak Swedish very well then. I completed my nursing degree in 1997 and the same year started my clinical work at an oncology ward. Since then I have completed specialist training in oncology nursing and worked in a variety of cancer services such as in-patient care, radiotherapy and now at an out-patient unit. I like the oncology work.

Working within oncology provides a good knowledge base about the human being, his/her strengths and weaknesses. To gain knowledge of what we can do to alleviate the burden related to the disease is important. Many advances in oncological care have been achieved recently, increasing survival rates. The management of symptoms related to treatment and/or the disease has also improved but these new treatments are also associated with new and sometimes difficult side effects. There are also individual aspects to consider, especially when it comes to symptom relief. I am interested in the aspect of quality of life in connection with the disease. I got the opportunity to start my PhD studies thanks to the contact with Freddi Lewin and his wife Nongnit Lewin, both senior researchers. They noticed my curiosity and together with a group from the medical laboratory, molecular biology, we started our translational collaboration. We studied the problem among our patients, took it to the experimental level with a wish that the results would be used to shape the care of cancer patients in the future. 
Having a good supervisor is a prerequisite for conducting research. Support from the clinic and the closest colleagues are also important factors influencing and improving research.

What it means to be an Oncology nurse, in my experience?

Oncology nurses follow the patient throughout the disease process from basic care to tumor-specific care and treatment. We plan and deliver the cancer treatment, share information and knowledge to ensure the right competences and skills are present within the rest of the care team. Cancer nurses contribution to patient care are essential $[4,5]$ as it involves patient safety promotion, the optimization of health and abilities, the prevention of illness and injury, the facilitation of healing, the alleviation of suffering throughout the stages of diagnosis and treatment as well as advocacy in the care of individuals and their families. The aim of nursing is to make sure that the person who requires care receive and benefit from the best health care. It also aims to eliminate patient health problems or alleviate them and meet the needs of the patient in terms of life and health [6-8]. In conditions when the patient is missing physical capacities, knowledge, will and motivation, the nurse can try to compensate this lack of resources with a helping hand and look for the right person in the rehabilitation chain for the person in question. Nursing care implies much more. Some important skills are to do systematic daily assessments, to give self-care advice and symptom management in the best way and also find new paths with the help of research [9]. 


\section{Introduction}

Cancer is one of the major public health problems today and a main cause of health-related fear and anxiety for people in Sweden [10,11]. One major reason for fearing cancer is due to the negative effects of the disease, but another is the fear of the treatment and its secondary effects. Most people lack knowledge of what a cancer patient looks like, how they feel and how it affects their quality of life (QoL) [12-14].

In this thesis I will present our findings as related to the predictors of sideeffects and toxicity from cancer treatment and provide insights into how this new knowledge can be used to reduce said toxicities and improve the quality of life for cancer patients undergoing treatment.

From a nursing viewpoint the first part explains cancer in general terms, followed by a general description of breast cancer (BC) since three of the four papers in the thesis deal with BC patients. Translational work and the implementation of genetics predictors in order to individualize the symptom relief are explained with a focus on the patients' health-related quality of life (HRQoL) [15].

\section{Cancer}

The incidence of cancer is increasing in general with contributing factors being an aging population and lifestyle factors such as smoking, alcohol habits, poor diets, inactivity and heredity factors. In Sweden, more than 60 000 cases per year is reported [10]. Common treatments for cancer are surgery, chemotherapy (CT), radiotherapy (RT), endocrine therapy, immune therapy and targeted therapies, depending on the form of the cancer and the 
stage of the disease. For most types of cancer, improved treatment results allow many patients to live longer and to be under treatment for longer periods of time thus increasing the prevalence of the disease. Therefore, many cancer forms have become chronic diseases and patients die of other causes of death, e.g. stroke, heart failure or old age. But for the patient the cancer diagnosis itself may give stress and lead to depression as well as existential anxiety in their daily lives [16]. In addition, the treatment-related side effects are often significant for the patient's well-being resulting in a reduced quality of life for example hair loss, fatigue and cognitive problems as well as insomnia. The most common acute side effects related to CT are nausea [17] and a decreased production of white blood cells [18]. Anxiety is a major concern for many patients and might result in delayed treatment [19-21].

\section{Breast cancer}

$\mathrm{BC}$ is the most common form of cancer among women and a common cause of death among women worldwide $[22,23]$. In Sweden the incidence is aproximatelly 9000 new cases per year. About $1 \%$ of the BC cases are men. The median age at diagnosis is 66 year. Relative 5 years survival is $85-92 \%$ and 10 years $73-86 \%$. There are multiple factors known to be associated with BC; menstrual age (both onset and ended), menopause age, obesity and alcohol consumption $[24,25]$. About $5-10 \%$ of BC cases have a heredity cause and 2,5-5\% have mutations in the BRCA1 or BRCA2 genes [26-28]. The neoadjuvant and adjuvant medical treatment of $\mathrm{BC}$ is based on the biological properties of the cancer and the risk of relapse, for example estrogen receptor (ER- $\alpha=$ nuclear receptor pathways), antiestrogen therapy; progesterone receptor (PR) progesterone antagonist therapy. Cytostatic 
agents are key elements of the treatment of primary BC with these drugs reducing the risk of recurrence. Every seventh woman with BC has a HER-2 (human epidermal growth factor receptor 2, a protein that is encoded by ERBB2 gene, an oncogene that has the possibility to generate cancer) positive cancer and therefore anti-HER-2 drugs are prescribed and combined with cytostatic drugs as a standard treatment in addition to surgery and RT $[29,30]$.

The care of these women includes assisting in the various problems that cancer carries on. Nursing involvement on emotional care has shown to increase the sense of control for the women throughout the period of diagnosis and primary treatment [31]. Amongst other things the women undergo a life crisis and the psychological factor that a cancer diagnosis gives plays a significant role in the life of the individual. They need to experience meaningfulness and joy in their present situation. Some women need more support than others, not just from caregivers; some need professional help [32]. They need information adapted to the situation and they need to know what is expected of the treatment, its side effects as well as about rehabilitation. They also need to know what they can do themselves to manage the disease and the side effects. And not least a trust between health people and patient has to be established [33].

\section{Chemotherapy}

Systemic adjuvant/neoadjuvant chemotherapy for BC often includes anthracycline regimens [34]. These drugs are known to give significant chemotherapy-induced nausea and vomiting (CINV) in various degrees. Acute CINV appear in general within $24 \mathrm{~h}$ after treatment in $40-60 \%$ of patients and delayed CINV appear within 5-10 days after the start of 
treatment in $40-80 \%$ of the patients $[35,36]$. First line CT treatment for BC is often FEC (Fluorouracil, Epirubicin and Cyclophosphamide) or EC (Epirubicin and Cyclophosphamide) which are medium to high emetogenic regimens [34].

\section{Epirubicin}

Epirubicin is an anthracycline (extracted from Streptomyces bacterium) and activates by intercalating DNA strands, inhibiting DNA- and RNA

synthesis. It results in mechanisms that lead to cell death and generates free radicals that cause cell- and DNA damage [37].

\section{Cyclophosphamide}

Cyclophosphamide is a nitrogen monosaccharide derivative. The drug is inactive and must be metabolized in the liver into 4hydroxycyclophosphamide to give rise to an alkylating substance. The resulting substance is an alkylating cytostatic that creates double bonds and breaks in the DNA strands resulting in cell apoptosis [38, 39].

Fluorouracil (5-FU)

5-FU works in several ways. The principal is interrupting the action of the enzyme thymidylate synthesis that is necessary for DNA replication [40].

Until 2016 FEC was the main treatment for BC in the most cancer centers in Europe. The treatment was then modified to EC, after a large randomized phase III study showing that no difference in disease-free survival exist using 5-FU. The study also showed no difference in toxicity of neutropenia, incidences of fever and nausea as well as vomiting compared with FEC [34]. FEC is administered nowadays only in selected cases. 


\section{Side effects of treatment}

$\mathrm{BC}$ is a heterogeneous disease. There is no unique therapy fit for all tumors of the breast [41]. The neoadjuvant/adjuvant systemic treatments aim is to prevent the recurrence of $\mathrm{BC}$ by eliminating micro-metastatic tumors that are present at the time of diagnosis or to decrease the size of the tumor before surgery. Patients receiving CT are prone to suffer from many adverse drug reactions [23]. On occasion these side effects can be triggered by underlying symptoms of anxiety, depression and a poor adherence to the medications used to prevent those symptoms [42, 43]. Clinical experiences show that patients treated with CT or RT in an adjuvant or palliative setting may experience very different side effects on the individual lever despite receiving similar treatment. This has raised the hypothesis that the genetic background of the patient could influence the intensity of side effects and thus also the amount of patients suffering as a result of treatment $[44,45]$. Reasons for interrupting cancer treatment (even if it successfully leads to tumor regression) include high-intensity side-effects of any kind.

Nausea and episodic vomiting are estimated as a primary burden for patients who are undergoing CT $[17,46]$. On the other side, patients who are treated with RT as the first oncological treatment after surgery may present other symptoms like acute radiation skin reaction (ARSR) [47-49]. Patients treated with RT like those treated with systemic CT, may also suffer from similar symptoms but these will be local (from the irradiated area).

\section{Nausea}

The intensity and frequency of CINV are useful to know how serious these side effects are [50]. CINV can lead to anorexia, metabolic problems, gastritis and/or problems with the esophagus such as fissures [18, 51, 52]. 
Evidence exists that a women's age $(<50$ years) is a predictor of CINV. Physical activity, morning sickness and the consumption of alcohol are other well-known predicting factors $[18,36]$. CINV includes both acute and delayed nausea and vomiting and the term "anticipatory nausea and vomiting" (ANV) includes conditioned nausea and vomiting [53-55]. Conditional nausea and vomiting can be affected by previous experiences. For example, if a patient is unwell and/or vomited during previous treatments, only the smell of the hospital can induce nausea and vomiting [56]. Nausea and vomiting that occur within 24 hours after chemotherapy are referred to acute while nausea and vomiting that occurs after 24 hours is called delayed $[55,56]$. The delayed nausea usually peaks on the third day following the initiation of CT and may persist for up to a week or more [56].

\section{Mechanism of nausea}

Nausea and emesis are commonly used concepts [46]. Nausea is an unpleasant sensation from the pharynx and the gastrointestinal tract that gives rise to the feeling that you will soon need to vomit. Nausea is something that happens before vomiting. Usually, nausea does not lead to vomiting and it has many different metaphors like a diffuse unpleasant sensation from the stomach or feeling of anxiety, disgust, exhaustion and pallor [52]. The degree of nausea can only be assessed by the affected person herself. The physiological causes of nausea are not fully understood but it is known that among other things, cytostatic drugs damage cells in the intestinal wall. This damage leads to the secretion of serotonin which stimulates the 5-HT3 receptors of the vagus nerve and further impulses to the vomiting center in extended marrow [56] (Figure 1). 


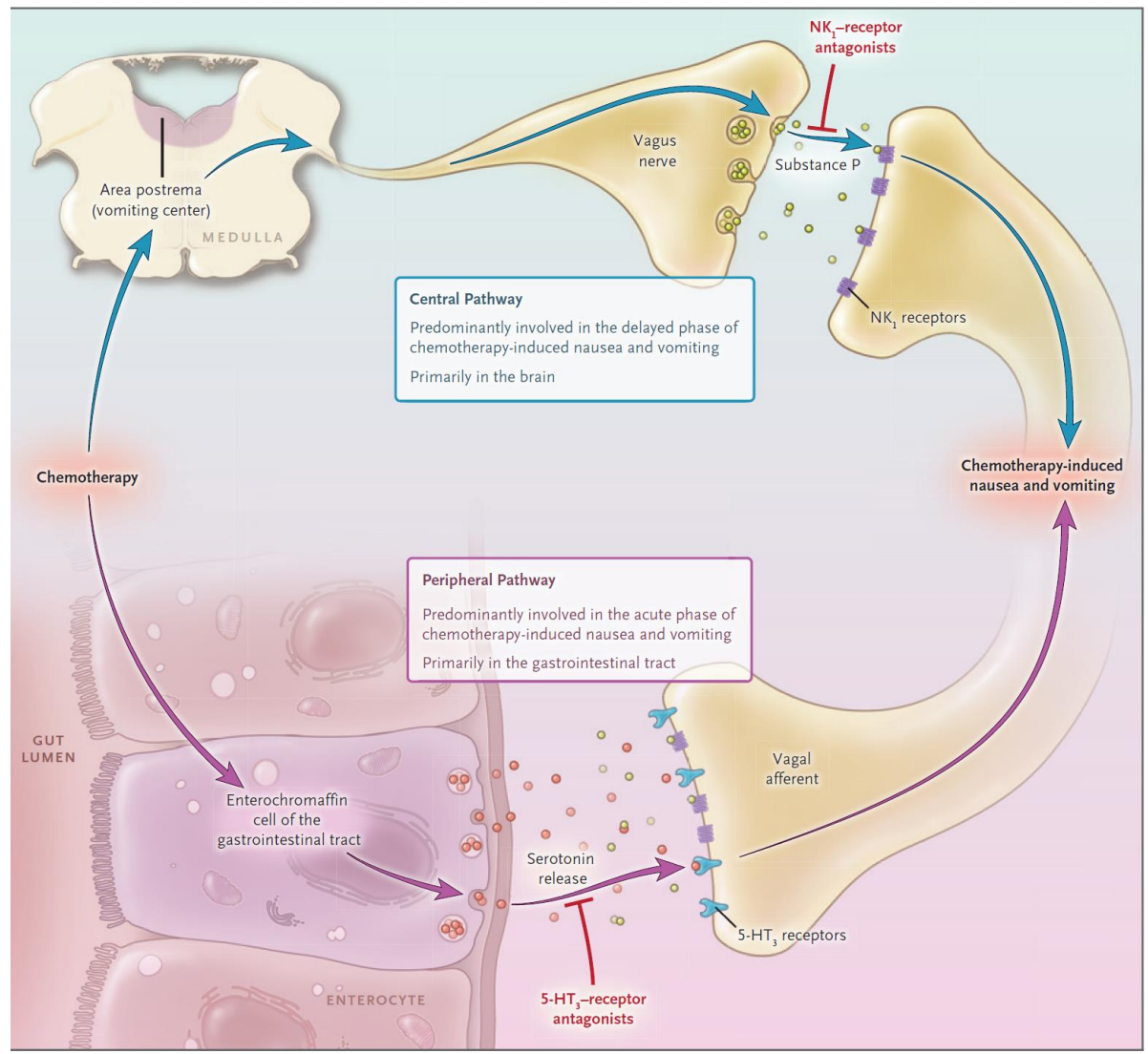

Figure1. Pathophysiology of Nausea and vomiting related to chemotherapy. 5-HT3 denotes

5-hydroxytryptamine type 3, and NK1 neurokinin-1 (Reproduced with permission from (N

Engl J Med 2016; 374:1356-1367), Copyright Massachusetts Medical Society). 
Nausea also has a protective function activated when a toxic substance is administered. The idea is that the nausea should prevent the individual from taking more of the toxic substance. The body is prepared with detectors that trigger the need to vomit. The main impulses can come from one or more of the following: the gastrointestinal tract, an area of the brain called the chemoreceptor trigger zone (CTZ), the inner ear, and higher brain centers that take care of "emotional" stimuli such as the desire to vomit [56]. The CTZ stimulates the CINV center by enterochromaffin cells within the gastrointestinal mucosa via the receptors: serotonin (5-HT), dopamine (D2) and neurokinin (N1) [17].

The new antiemetic accessible drugs are effective and stop the vomiting reflex in different ways. The recommendation is to give to all patients who obtain highly emetogenic CT regimens a combination of three-drugs containing a neurokinin 1 receptor antagonist, a 5-hydroxytryptamine-3 (5$\mathrm{HT}^{3}$ ) receptor antagonist as well as dexamethasone. Antiemetic management is stated by a guideline from the Southeastern health region in Sweden based on the American Society of Clinical Oncology antiemetic guideline [57]. Despite all new drugs, nausea remains a clinical problem [58, 59] (Table 1). 
Table1. Antiemetic dosing by Fluorouracil, Epirubicin and Cyclophosphamide (FEC) or Epirubicin and Cyclophosphamide (EC) treatment in the southeastern region in Sweden in 2019

\begin{tabular}{|c|c|c|}
\hline Antiemetic dosing by EC /FEC treatment & the southeastern region $\mathrm{i}$ & eden in 2019 \\
\hline $\begin{array}{l}\text { Emetic risk category: High includes } \\
\text { combination of anthracycline and } \\
\text { cyclophosphamide. }\end{array}$ & $\begin{array}{l}\text { Dose on day of } \\
\text { chemotherapy }\end{array}$ & Dose on subsequent days \\
\hline $\begin{array}{l}\text { Combined } \mathrm{NK}^{1} \text { receptor antagonist and 5- } \\
\text { HT }^{3} \text { receptor antagonist Akynzeo (NEPA) }\end{array}$ & $\begin{array}{l}300 \mathrm{mg} \text { netupitant and } 0.5 \\
\text { mg palonosetron orally }\end{array}$ & \\
\hline $\begin{array}{l}\text { Corticosteroid if Akynzeo (NEPA) is used: } \\
\text { Dexamethasone }\end{array}$ & $12 \mathrm{mg}$ orally or IV & $\begin{array}{l}8 \mathrm{mg} \text { orally once daily on day } 2 ; 4 \\
\mathrm{mg} \text { orally once daily on day } 3-4 \text {. }\end{array}$ \\
\hline
\end{tabular}

\section{Radiotherapy-induced skin reactions}

RT induces DNA damage leading to a cell cycle arrest followed by cell death [60]. If a cell population is irradiated with 2 Gy, nearly $50 \%$ of the cells will survive without evident damage. This is because the cells can repair DNA damage regardless of which toxic mediator induced them [61]. On the other hand, this could be particularly toxic to normal tissue (skin) since the timing of damage expression can vary widely between different normal tissues and the tumour [62]. In the skin, this normal tissue damage appears as different reactions with examples ranging from redness to flaking, eruptions and inflammation. The individual variations in ARSR suggest that genetic differences in combination with other risk factors such as the dose and volume of irradiation, the RT technique and type of surgery as well as other personal characteristics as high body mass index (BMI), breast size, skin type, might be one explanation of the individual variations $[48,60,63,64]$. 
Conventional adjuvant RT after BC surgery requires 5 weeks of daily treatments (Monday to Friday), $50 \mathrm{~Gy}$ in 25 fractions (2 Gy per fraction) [65]. During the last decade a more hypofractionated treatment has been introduced $(2,66 \mathrm{~Gy} \times 16$ fractions $=42,56 \mathrm{~Gy})$ [66]. The treatment has some implications on QoL because the patients experience a larger variation in normal tissue toxicity [67]. The ability to predict a patients risk of developing severe ARSR is difficult in patients treated with RT even with the last decades of gained knowledge on ARSR risk factors [48, 64]. Most patients experience mild ARSR with different degrees of erythema being prevalent [68]. It is indispensable that any injury is minimized as far as possible by guaranteeing that interventions are grounded upon best practice and supported by evidence-based guidelines like the Radiation Therapy Oncology Group-scoring assessment [69]. A smaller proportion (20\%) of patients experience more severe ARSR with dry and/or moist desquamation which is often associated with discomfort, itching, pain and/or disturbed sleep patterns $[70,71]$. ARSR normally appear one to two weeks into the course of RT, accelerating during the treatment period reaching a peak approximately ten days after the completion of RT [47, 48].

\section{Sleep}

As the approximately $24 \mathrm{~h}$ cycle of light and darkness was present even before the first living organisms, the circadian clock has been integrated into almost every aspect of physiology both at the cellular level (metabolic control, management of reactive oxygen species, DNA synthesis and cellular replication) as well as at the systemic level (regulation of heart rate, blood pressure, muscle activity, sympathetic and immune system activation) $[72,73]$. The mechanism starts in the eyes that perceive the light or darkness 
and send signals up to the hypothalamus which receives signals via the retinohypothalamic path to the suprachiasmatic nucleus making the person feel tired. The brain then sends a signal through the cervical sympathetic chain to the pineal gland and melatonin starts to become produced and secreted to the organism. Slowly, one falls asleep [72, 73].

\section{Sleep disturbance}

Poor sleep is a common symptom reported by cancer patients undergoing medical treatment [74]. Poor quality of life (QoL) can lead to sleep disturbances. In the same way, poor sleep quality can have a negative influence on the QoL [74] (Figure 2). The patients experience difficulty working and coping with family life and daily living [75] Some of the changes that occur in the body when the circadian rhythm is disturbed can be detected in the blood or in the urine. For example, cortisol and melatonin are found mainly in the blood and/or urine during the day and at night respectively $[76,77]$ and increased levels of inflammatory factors IL-6 and $\mathrm{TNF} \alpha$ are linked to sleep disorders [78]. In blood cells, the circadian rhythm is mainly regulated via the genes Bmal1 and Period2 [79]. However, if these genes can be used as a measure of sleep disorders in cancer patients and the relationship between sleep disorders and life-threatening medical treatment is still poorly investigated. 

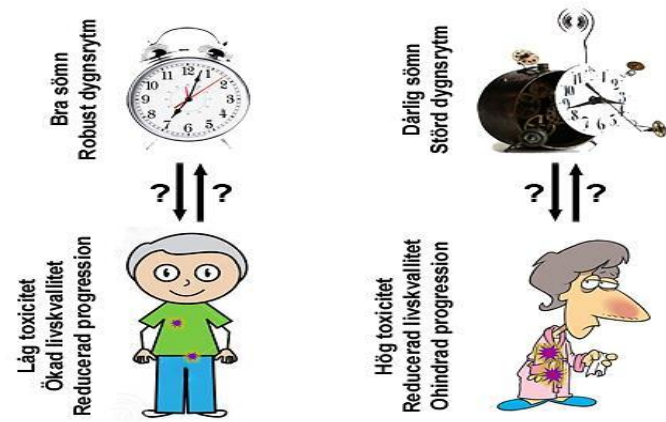

Figure2. Relations about sleep well and bad sleep (picture by Lasse Jensen and published with permission for this purpose)

\section{Translational cooperation in research}

To do research you need to work together with others. Collaborative practice and research occurs when disciplines from more than one health profession work together with the aim of creating new knowledge that can bring increased quality to patient care. Within the healthcare sector it is common to cooperate with different professions to achieve a desired result [80]. In medicine and in care the term "translational" is used to indicate cooperation between pre-clinical researchers and professions involved with the care of the patients. The term came into use in the 2000s but the working method as such is not new. The word "translational" comes from the Latin "translatio" = transmission and is a school for medical research based on the close and mutual exchange of knowledge on specific healthcare cases. The research is therefore based on the health status of the patient and aims to 
quickly achieve results that can lead to a better diagnosis and treatment of the patient [81].

In present times, translational research is a well-established method globally. This is a common method to implement new knowledge through collaborative research in the medical world [82]. The aim is to "translate" the knowledge of mechanisms and techniques within basic scientific research into new methods of diagnosis and treating diseases. Translation in the opposite direction is also emerging as a highly relevant research area, namely the translation of clinical observations to new hypotheses within basic scientific research. This two-way process is often referred to as "triple B" or "from Bench to Bedside and Back again" $[82,83]$. The research in this thesis is partly translational (papers II and III). As an oncology nurse, I realized that women with $\mathrm{BC}$ who received the same $\mathrm{CT}$ and $\mathrm{RT}$ experienced toxicity differently. Having mapped the differences, collaboration with a physician and a biologist was established to see what could explain these individual differences. The studies found differences in the gene sets between the different individuals where we identified three variations in the genome that were found to be associated with the risk of nausea as well as two variations found to be associated with ARSR.

The evidence-base in medicine and nursing is large and growing. No profession alone can manage the knowledge required to conduct translational research. Thus, research networks and projects such as described in this thesis, could contribute to improvements in cancer care. 


\section{Health-Related Quality of life}

For health-related quality of life (HRQoL) the absence of disease is important but it is the feeling of complete physical, mental and social wellbeing that determines QoL [84] (see Figure 3). HRQoL is a term defined by the individual depending on the situation in which the individual is in. The term is subjective and describes what is studied at a specific time [12]. According to Naess [85], QoL consists of four parts within the individual: experiencing dynamics, satisfaction in relation to others, self-respect and joy in what you do while maintaining a holistic perspective.

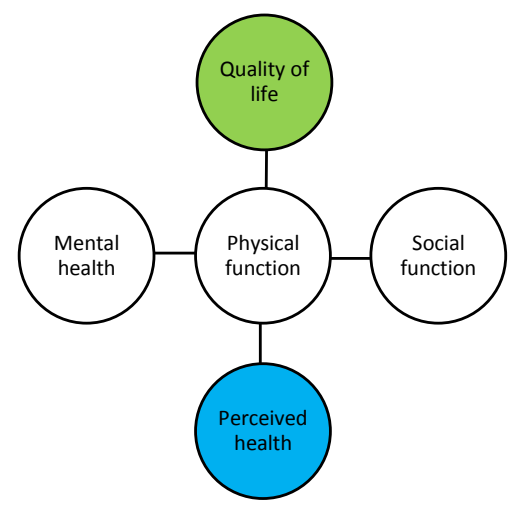

Figure 3 Perspectives of quality of life (figure by Delmy Oliva)

A sick person has a different determination of QoL with the difference depending on the individual valuation of the impact of the disease as well as 
the treatment on the physical, psychological and social domains of activity and well-being [3]. Health is a transformation between the limits of wellbeing and disease, suggesting that it is present for the whole life centering on the patient's personal capacity and other possibilities who contribute indirectly. Positive health results as the patient/person can appreciate their imperative goals under habitual situations and the patient has the accuracy to define and to choose what health means to them. Many patients have cognitive complaints or no strength to take care of themselves and family with health professionals sometimes needed to act as mediators and find out possibilities to increase their HRQoL [86]. Patients living with cancer may experiences ill health from both the acute and, more often from the prolonged side effects of the disease and/or the treatment. This may influence their entire life situation and thus their HRQoL. There are several ways to measure HRQoL and the European organisation for research and treatment of cancer (EORTC) has various QoL questioners for almost each type of cancer and a general questioner (EORTC QLQC-30) which measures QoL regardless of the type of cancer. The questioners are translated into different languages [87-89].

\section{Eastern Cooperative Oncology Group (ECOG- Performance Status)}

The patient Performance Status (PS) is a reliable indicator of a patients' general situation. In clinical practice, it is a necessary prognostic factor and a suitable tool while creating prognostic models for the prediction of survival and determining the choice of treatment. A more accurate PS assessment results in a better prediction [90-92]. 


\section{Genetics}

\section{Single Nucleotide Polymorphism definition and application on the clinical work}

Major contributors to individual variations in genetic profiles are Single Nucleotide Polymorphisms (SNPs) (Figure. 4). An SNP is defined as a variation of one nucleotide in which one allele is present in more than $1 \%$ of the studied population $[93,94]$. SNP is the most common variation in DNA and may result in an altered gene expression with different results found in protein production and responses to external factors such as drug metabolism.

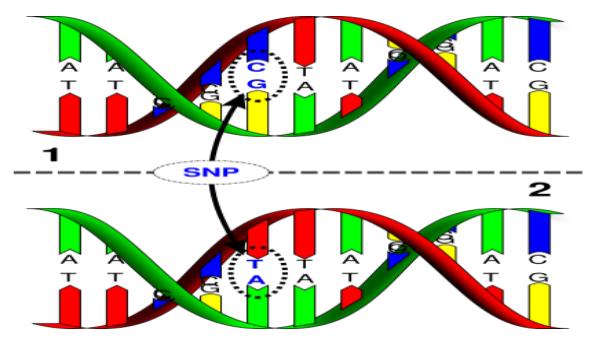

Fig. 4 Single Nucleotide Polymorphism in Deoxiribonucleinsyra (Source: David Hall, Wikimedia Commons, 2010)

SNP-analysis can be done before treatment and with certainty identify patients with an increased risk for developing the studied side effects and thus could be helpful to personalize treatments, information and self-care advice [58, 95]. 


\section{FAS/CD95 (Apoptosis-mediating Surface antigen FAS (CD antigen CD95))}

The gene is a member of the TNF-receptors; it includes a death derivation and assist in immune homeostasis, the elimination of transformed and infected cells and plays a fundamental role in surface tolerance as well as $\mathrm{T}$ cell stimulation. It is also responsible for avoiding inflammation in certain tissues. The gene plays a central role in the functional regulation of programmed cell death and is involved in the pathogenesis of several alterations and diseases of the immune system [96-98].

\section{RB1/LPAR6 (Riboblastom 1)}

The first tumor-suppressor gene recognized. Their functions are to control the cell cycle by adjusting the grade of phosphorylation and by this contribute in the regulation of cell growth and differentiation. It is expressed in all body cells [99-101].

\section{CCL2 (Chemokine (C-C motif) ligand 2)}

A chemokine-producing gene involved in the regulation of the immune system and inflammatory processes. This chemokine present chemotactic activity for monocytes and basophils and plays a key role in host protection as these cells guard potential places of microbial invasion and rapidly locate areas of tissue damage [102-104].

\section{IFNg (Interferon gamma)}

This gene encodes a cytokine. It is a protein involved in the adaptive immune systems (natural killer, NK and Natural Killer T, NKT cells). The active protein is composed of two identical polypeptide cuffs that bind to the interferon gamma receptor which produces a cellular response to viral and microbial toxicities. [105, 106]. 
XRCC2 (X-ray repair cross complementing 2)

This gene participates in particular to maintain chromosome stability and to repair DNA damage such as DNA double-strand breaks after radiotherapy $[107,108]$. 


\section{Aims of the thesis}

Overall purpose

The purpose of this thesis was to find biological markers that can identify risks or protective factors for CINV and to understand the possible heterogeneity. The purpose was also to understand the individual factors behind ARSR and sleeping disturbances in patients treated for cancer permitting a more individualized care and optimized HRQoL. The specific aims are to characterize and understand:

I Variations in self-reported nausea, vomiting and well-being during the first ten days post-chemotherapy in women with BC

II If single nucleotide polymorphisms might influence CT induced nausea in women with BC

III Whether individual genetic background predicts ARSR in women undergoing adjuvant BC RT?

IV How sleep disturbances affect cancer patients who are undergoing systemic adjuvant and/or palliative oncological treatment 


\section{Patients}

The thesis is based on four different studies. The table below (Table 2)

presents their designs and the number of the patients includes in the four papers and the time when they were executed.

Table 2. Summary of the included papers on the thesis

\begin{tabular}{lllll}
\hline Design & Paper I & Paper II & Paper III & Paper IV \\
\hline & $\begin{array}{l}\text { Longitudinal } \\
\text { quantitative } \\
\text { study with } \\
\text { repeated } \\
\text { measurements } \\
\text { for ten days }\end{array}$ & $\begin{array}{l}\text { Longitudinal } \\
\text { quantitative } \\
\text { study with } \\
\text { repeated } \\
\text { measurements } \\
\text { for ten days }\end{array}$ & $\begin{array}{l}\text { Longitudinal } \\
\text { quantitative } \\
\text { study with } \\
\text { two different } \\
\text { measurement } \\
\text { during five } \\
\text { weeks }\end{array}$ & $\begin{array}{l}\text { Cross- } \\
\text { sectional } \\
\text { cohort study }\end{array}$ \\
\hline Participants & $\begin{array}{l}\text { 39 women } \\
\text { undergoing }\end{array}$ & $\begin{array}{l}\text { 114 women } \\
\text { undergoing } \\
\text { CT }\end{array}$ & $\begin{array}{l}119 \text { women } \\
\text { undergoing } \\
\text { RT }\end{array}$ & $\begin{array}{l}\text { 90 } \\
\text { consecutive } \\
\text { patients with } \\
\text { different } \\
\text { diagnoses of } \\
\text { cancer }\end{array}$ \\
\hline $\begin{array}{l}\text { Study } \\
\text { period/inclusion }\end{array}$ & $2011-2012$ & $2011-2013$ & $2011-2013$ & $2017-2018$ \\
\hline Analysis period & $2013-2014$ & $2015-2016$ & $2016-2018$ & $2018-2019$
\end{tabular}




\section{Methods}

\section{Setting}

Jönköping's county hospital has a Department of Oncology with 12 beds, 130 co-workers, and a radiotherapy ward. The county hospital at Ryhov is responsible for all 356000 inhabitants within the county. About 40 patients are treated at the outpatient treatment unit every day. The treatment modalities are radiotherapy, chemotherapy, targeted drugs, immunotherapy, endocrine treatment and associated follow-up and care.

In paper II Växjö Hospital, Department of Oncology also contributed as a center of investigation. Växjö Hospital is placed in the county of Kronoberg.

\section{Paper I}

- Consecutive inclusion was used.

- A structured diary was used to record nausea, vomiting and wellbeing. The patients reported into the diary every morning and evening over a period of ten days (Appendix 1).

- A telephone interview was done after ten days to recover information about degree of nausea using a VAS scale (Appendix 2) (the patients was given a scale in the inclusion and was informed of the call). The other question was to indicate which of the ten days was considered the worst day (Appendix 3).

- The patients were treated with first-line chemotherapy FEC

- Svenssons method were used as statistical analyze (see statistics page 44) 


\section{Paper II}

- Self-reported nausea and vomiting was recorded in a structured diary over the ten days following treatment.

- Blood samples were collected before treatment (30 ml)

- 48 SNPs in 43 genes were used in this study. For the analyses the following methods were used: High molecular weight DNA was extracted from the blood using MagNa Pure LC2.0 (Roche Diagnostic, Switzerland). The quality and quantity of DNA were determined using the Nanodrop and Pico Green ds DNA assay. DNA (250ng) from each patient was used as the template for the SNP analysis. The identification of the SNPs was done by the Illumina Golden Gate Genotyping assay at the SNP\&SEQ technology platform, Uppsala University, Sweden (http://www.genotyping.se).

- The SNPs were selected out of those that are commonly known in opioid-related nausea, inflammation and toxicity conditions.

- The hypothesis has been that individual differences in toxicity might in part depend on differences in genes involved in cell cycle progression, cell death, DNA repair, cell functions and inflammation.

\section{Paper III}

- Consecutive inclusion was used.

- The whole breast was treated with two parallel opposing tangential fields using the Varian Linacc $2100 \mathrm{CD}$, (Varian medical systems, Inc, Palo Alto, CA USA). 6 MV or 6 MV combined with 15 MV 
photons in some fields, were chosen depending on the size of the treated breast. The treatments were prescribed to the $95 \%$ isodose according to ICRU (International Commission on Radiation Units and Measurements, 2014)-standards in a 3-dimensional treatment planning system (Oncentra masterplan v 4.3, Elekta AB, Stockholm, Sweden). Areas receiving $90-105 \%$ of the dose were accepted. The absorbed dose was $50 \mathrm{~Gy}$ in 25 fractions given as one fraction per day, five days per week with an overall treatment time of five weeks. Neither gating nor boluses were used. However, four patients were treated with a hypofractionated RT-schedule of 42,56 Gy in 16 fractions, 1 fraction per day, 5 fractions per week.

- Itching, burning and irritation were self-reported twice over the five weeks of treatment using the VAS-scale as measurement.

- The RTOG-scale (Radiation Therapy Oncology Group) scoring system for acute RT was used for the assessment of the irradiated skin. The scoring generally used for objective assessment of skin reactions is the Radiation Therapy Oncology Group (RTOG) grading system [69]. This system is a very simple guide which can help health care providers facilitate a constant approach to skin assessment (Appendix 4 with Swedish translation). The RTOG grading system is indispensable, helping ensure that the right support is applied at the correct time in response to constant assessments and evaluations.

- Blood-based SNP analysis was performed using peripheral blood samples obtained before treatment and analysed in the same way as described in paper II. 


\section{Paper IV}

The measurements were done twice, before the start of treatment and three months after ongoing treatment.

- The MOS Sleep Scale was used to measure sleeping patterns.

The MOS sleep scale consists of 12 items to measure with examples including the time to fall asleep, hours of sleep each night, sleep longevity, respiratory problems, perceived adequacy and somnolence. The two first questions are recorded with specific numbers and the ten others have a five-point Likert scale where "1" means "all the time" and " 5 " signifying "none of the time". The time-frame of responses cover the previous 4 weeks (Appendix 5 with Swedish translation) [109].

- Open-ended questions

- The EORTC QLQ-C30 questionnaire was used to measure HRQoL.

It's a questionnaire-core established to assess the quality of life of cancer patients using 30 questions. The questions are built on five function domains e.g. physical-, emotional-, social-, role- and cognitive values. It includes eight symptoms such as fatigue, pain, nausea/vomiting, constipation, diarrhea, insomnia, dyspnea and the loss of appetite. Questions from 1 to 28 were structured with four alternatives from "not at all" to "very much". Furthermore, the questionnaire also inquired about global health/quality of life and financial impacts (questions 29 and 30) with these questions are scored from 1 to 7 , where 7 are the best score and 1 the worst. The questionnaire is very usefully to understand current QoL in all positions 
of the treatment. The information was collected over a period of four weeks following treatment (Appendix 6 with Swedish translation) [88, $110]$.

- Svenssons method were used as statistical analyze (see page 44, statistics). 


\section{Ethical considerations}

All four papers have been approved by The Regional Ethical Review Board which follows the Helsinki declaration of ethical principles for medical research involving humans.

Paper I, II and III

The Regional Ethical Review Board in Linköping approved the study (Dnr 2010/331-31, December 2010).

Paper IV

The Regional Ethical Review Board in Linköping approved the study (Dnr 2016/379-31). 


\section{Statistics}

Descriptive statistics, numbers, medians and percentages were used to describe the patient population. The genotypes and allele frequencies were quality checked. For SNPs where no genotypes were found to fulfill the Hardy-Weinberg equilibrium $^{1}$ (HWE, Chi2 test, $\mathrm{p}<0.05$ ) as well as a minor allele frequency $(\mathrm{MF})<5 \%$ these were discarded from the analysis. Oddsratios and $95 \%$ confidence intervals were calculated to evaluate if the SNPs were associated with a change in the risk for nausea. Confidence intervals (95\%) and significance levels were calculated. A significance level of 5\% was considered as statistically significant; however this must be valued by clinical relevance. When data collection was made over time, repeated measurement analysis was used where appropriate to decrease the risk of false positive results.

\section{Svenssons method as statistical analyse in paper I and IV}

The outcome from the patient-reported instruments consisted of paired ordered categorical data, that is, response categories can be ranked, but do not have a numerical property, as for instance a blood pressure. For paired ordinal categorical data (patient-reported), the responsiveness of treatment

\footnotetext{
1 Hardy-Weinberg equilibrium principle states that allelic frequencies will continue the same from generation to generation if the population is constant and in genetic equilibrium. This is significant to give biologists a regular from which to measure alterations in allele frequency in a cohort. $\mathrm{p}+\mathrm{q}=1$

$\mathrm{P}=$ frequency of dominant allele $q=$ frequency of recessive allele $\mathrm{p}^{2}+2 \mathrm{pq}+\mathrm{q}^{2}=1$ 
and nausea and sleep disturbance were analyzed using Svenssons method which is developed especially for this kind of data. This method characterizes the direction and size of differences in self-reported effects between baseline and follow up, as well as variation in response pattern and heterogeneity in the eventual change within or between groups. This method is suitable for getting insights into the patient pattern of response to interventions or different treatments and could be used to individualize the management of the patient care. The Svensson method is developed for both Likert-type and Visio-Analogous (VAS) responses.

Paper I and paper IV were analysed using the Svensson method, which is becoming a more widely used statistical method $[112,113]$. The calculation is easy to perform (Excel macros with instruction manuals are available for downloading [114] in order to analyze changes within patient groups. The method reveals if patients either improves, deteriorates or stay stable on an individual level due to treatment. The algorithm assumes an ordered structure of the data and is suitable for all types of information that have this single property. The use of other non-parametric methods, as McNemars Test, only reveals if there is a change but reveals nothing else, and that is insufficient for our purpose in these studies.

For analyzing change on an individual level, it is important to consider that the data consists of paired observations, two values (or more) per individual. The distribution of the data pairs in the contingent table or scatter plot offers an excellent description of the change pattern and the marginal dispersion provide extra information on the frequency distribution of the assessments at each time. 
Thanks to the special ranking method with paired responses, it is possible to statistically measure the group-related change separately from the individual deviations. The group change is measured by two parameters, partly the degree of change in the Relative Position on the scale (RP, the difference between the probability of improvement and deterioration, varies between 1 and +1 ) and the Relative Concentration ( $\mathrm{RC}$, varies between -1 and +1 , a systematic shift in the concentration of ratings to the middle of the scale, as the difference between two probabilities similar to RP). A positive $\mathrm{RC}$ is a sign that the responses are more concentrated towards the center at follow up whereas a negative $\mathrm{RC}$ indicates a more concentration in the middle at baseline. The percent agreement (PA) reveals the proportion of individual that remains unchanged. The individual variability is estimated by the Relative Rank Variation ( RV, varies between 0 and +1 , whereas it should exceed 0.20 to be of an indication individual change from a common pattern of change).

High values of RP and / or RC and low values of RV indicate homogeneity in change patterns for the studied group.

High values of RV indicate individual deviations from a common pattern of change, thus the presence of a heterogeneous, individual pattern of change $[115,116]$.

The parameters PP, RC and RV are presented with standard errors and 95\% confidence interval. Since the standard error is calculated it is possible to compare the results from two or more patient groups. 


\section{Results}

The first three papers study BC and CINV related to CT and ARSR. The results show clinical outcomes and the possible role of biomarkers in individualizing treatment for symptom relief thus effectively preserving the HRQoL of the treated patients. The fourth paper studies sleep disturbances for patients in systemic oncological treatment, the influence of the problem and how the HRQoL is affected.

\section{Paper I}

We found a variation in estimations of nausea and less variation in actual vomiting. Women older than 50 years experienced more delayed nausea with 5 women experienced vomiting. Women younger than 50 years experienced more acute nausea. The change in nausea between the two measurements points exhibits no uniform pattern of change in any direction. Thus, the experience of nausea was very heterogeneous as seen in Figure 5.

For $74 \%$ of the women the day assessed as the worst was the day they felt ill, experienced nausea, vomited or felt bad for any other reason for. 


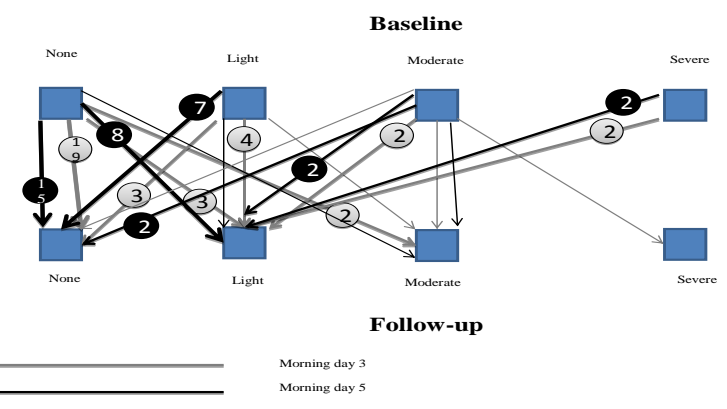

Figure 5: Arrow diagram showing the changes in the estimated nausea between baseline (evening of day one) and the morning of day three and day five. The numbers in circles indicate the number of women who have moved from the response at baseline to the follow-up. Arrows without numbers show the result from a single woman.

Regarding well-being, the experiences varied and were dependent on the absence of nausea and vomiting. Among the thirteen women who scored low (bad or very bad) on well-being at baseline, estimations of well-being varied for the morning of day three. More than half of these women experienced that well-being improved from day one to days three or five. 


\section{Paper II}

CINV was reported by $84 \%(n=96)$ of the patients. Two groups (stratified by age) young women $(n=34) \leq 50$ years old, reported more nausea than the older women $(n=80)>50$ years old $($ Table 3$)$.

Table 3 Reported nausea during the first 10 days after the start of chemotherapy.

\begin{tabular}{|c|c|c|c|c|c|}
\hline $\mathrm{n}=(\%)$ & & & & & \\
\hline No nausea & Acute nausea & Acute and delayed nausea & Delayed nausea & Age & \\
\hline $1(2)$ & $7(21)$ & $22(65)$ & $4(12)$ & $27-50$ & $(30)$ \\
\hline $17(21)$ & $6(8)$ & $32(40)$ & $25(31)$ & $51-83$ & $(70)$ \\
\hline $18(16)$ & $13(11)$ & $54(47)$ & $29(25)$ & Total & 114 \\
\hline
\end{tabular}

\section{SNPs associated to nausea}

Statistical significance for nausea was found with the limitation for an $\mathrm{OR} \geq$ 2.0 and a $p$-value $\leq 0.05$ in three SNPs: CCL2 rs 2530797 , FAS/CD95 rs2234978 and RB1/LPAR6 rs 2854344. 
The worst day in terms of well-being was associated with the day of the highest reported VAS score for CINV (Figure 6).

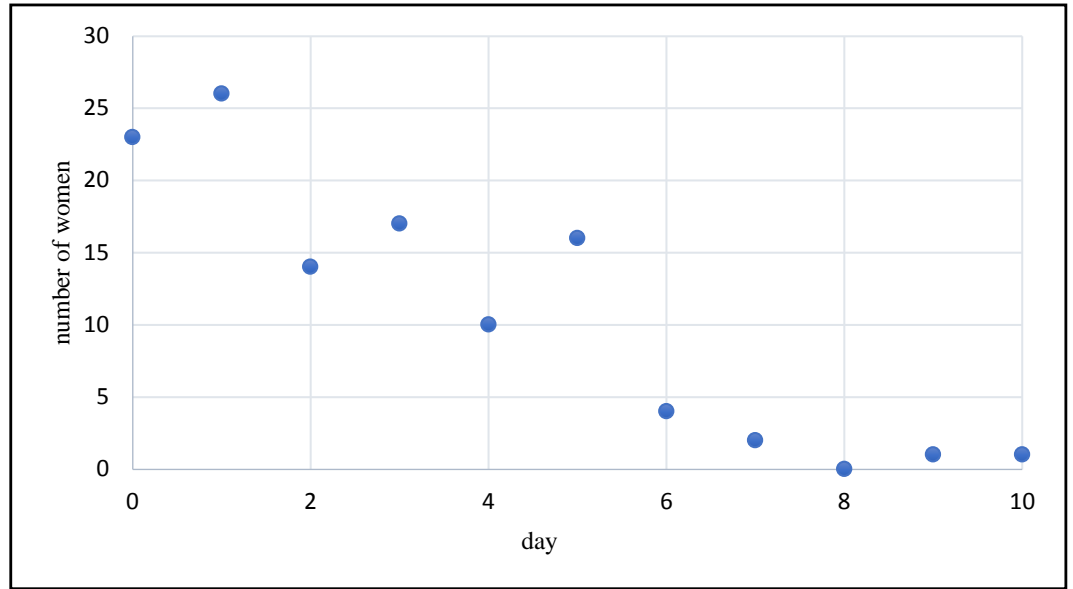

Figure 6: Self-reported days of the most intense side effects during the first 10 days following the start of chemotherapy. Twenty three women reported no special day. This is marked in day 0 in the figure.

\section{Paper III}

The women were treated with RT for BC with standard RT, $50 \mathrm{~Gy}$ in 25 fractions, 1 fraction per day, 5 fractions per week. Four of the 119 patients were treated with 42,56 Gy totally in 16 fractions, 1 fraction per day, 5 fractions per week.

\section{Assessment of acute radiation skin reactions (ARSR) and related symptoms}

During the first week of treatment none of the women reported any symptoms related to RT. During the fifth week of RT all patients were assessed to have ARSR, scored as RTOG 1, 2 and 7,5\% (n=9) as RTOG 3. 
At the same point in time, the women reported itching ( $n=97,82 \%)$, irritation $(n=96,81 \%)$ and burning $(n=64,53 \%)$ from the irradiated skin area (Figure 7). Neither smoking nor having had CT before RT did not have any influence on the acute toxicity of the skin, nor were high BMI-values associated with ARSR measured by the VAS-scores for related symptoms or the RTOG-score.

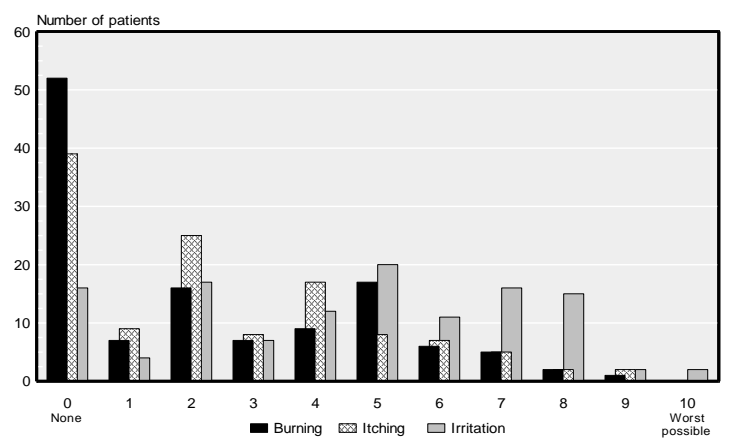

Figure 7 Self-reported symptoms during radiotherapy (last week of treatment): burning, itching and irritation reported on a ten-graded Visual Analogue Scale among 119 treated females. The side-effects are irrespective of treatment with moisturizer or corticosteroid cream.

As a standard recommendation for patients undergoing RT in the Department, 77 women (68\%) were prescribed a topical corticosteroid cream (Betamethasone 0,1\%) at different occasions during RT. The remaining 37 women $(32 \%)$ were recommended only the moisturizing cream (Essex $\left.{ }^{\circledR}\right)$ throughout the RT period (Figure 8). 


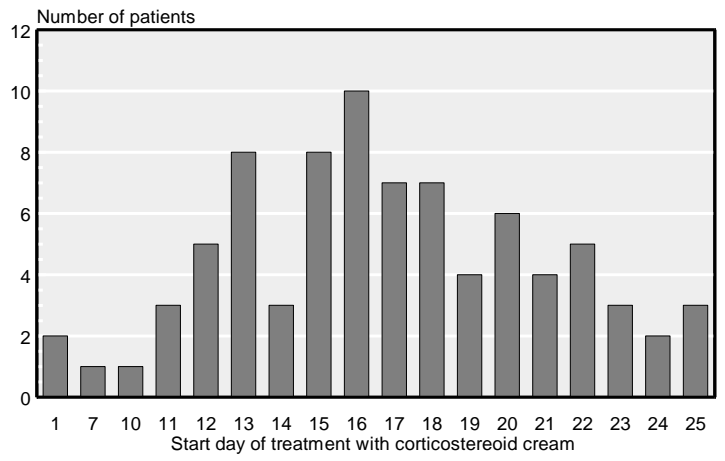

Figure 8 Shows starting day during radiotherapy for corticosteroid cream treatment of Acute Radiations Skin Reactions (ARSR)

\section{SNP and ARSR}

Two SNP were found, one associated with itching in gene IFNg rs2069705 and the other one was associated with burning and/or irritation in gene XRCC2 rs2040639.

\section{Paper IV}

\section{Sleeping habits}

Ninety patients undergoing treatment for a variety of cancer diagnoses were included in the study. At the inclusion 18 of 72 patients (25\%) stated that they had sleeping problems. The results from the MOS sleep scale showed that $58 \%$ of the patients reported sleeping problems. In the open-ended questions $30 \%$ of patients were found to experience insufficient sleep both at baseline and follow-up (Table 4). 
Table 4: Patients reported sleep quality in the open-ended questions.

\begin{tabular}{|c|c|c|}
\hline \multirow[t]{2}{*}{ Describe how you experience the quality of your sleep? } & \multicolumn{2}{|c|}{$\mathrm{n}=(\%)$} \\
\hline & Baseline & Follow-up \\
\hline 1. Good/well & $46(58)$ & $35(48)$ \\
\hline 2. Good sleep but only after using sleep pills & $5(6)$ & $6(8)$ \\
\hline 3. Insufficient & $24(30)$ & $22(30)$ \\
\hline 4. Missing data & $5(6)$ & $10(14)$ \\
\hline Total & $80(100)$ & $73(100)$ \\
\hline \multicolumn{3}{|l|}{ What you think may be the cause of any sleep problems? } \\
\hline 1. Nocturia & $6(7,5)$ & $13(18)$ \\
\hline 2. Disease/cancer & $20(25)$ & $7(10)$ \\
\hline 3. Anxiety & $18(22,5)$ & $16(22)$ \\
\hline 4. Pain & $1(1)$ & $1(1)$ \\
\hline 5. Missing data & $35(44)$ & $35(49)$ \\
\hline Total & $80(100)$ & $72(100)$ \\
\hline \multicolumn{3}{|l|}{ Describe your sleep pattern? } \\
\hline 1. Sleeps mostly at night & $76(95)$ & $61(84)$ \\
\hline 2. Sleep mostly at day & $1(1)$ & $1(1)$ \\
\hline $\begin{array}{l}\text { 3. At night some days and at day some days on the } \\
\text { week }\end{array}$ & $1(1)$ & $3(4)$ \\
\hline 4. Missing data & $2(3)$ & $7(11)$ \\
\hline Total & $80(100)$ & $72(100)$ \\
\hline
\end{tabular}

Sleeping time (hours of sleep) was not remarkably different between baseline and follow up, with the mean change being nine minutes more at follow up according to the MOS sleep scale. This is not statistically significant.

The reported reasons for sleeping disturbances were nocturia, cancer disease and anxiety. Ninety-five percent $(n=76)$ of patients reported sleeping during the night at baseline and $84 \%(n=61)$ at follow-up. Anxiety as the cause of sleeping disturbances was equal between the first and second measurements. 
Nocturia increased at follow-up. Living with the disease as the cause of sleeping problems decreased from $25 \%$ to $10 \%$.

\section{Health-related quality of life (HRQoL)}

HRQoL measured by the EORTC QLQ C- 30 questionnaire showed that fatigue was increased at follow-up when compared to baseline. Patient reported a need to sit or stay in bed more often, experienced limitations in social activity levels both in terms of family- and social life. HRQoL fluctuated from very poor to excellent with individual variability. The HRQoL was thus heterogeneous. In the two symptoms scales (the MOS sleep scale and EORTC QLQ- C30) fatigue increased. The patients reported that they became more tired and needed to rest more during the day. 


\section{Discussion}

The main purpose of the studies we have conducted was to describe individual variations as well as possible relationships between symptoms and genetics with the ultimate objective of minimizing the side effects of the oncological treatments that patients undergo. The central interests are to personalize the treatment of the side effects with help of biomarkers as we know that individuality also exists in the reaction to oncological treatments. The first (I) and second (II) papers are studies about individual variation of nausea, vomiting and well-being related to CT treatment. In study I we found an individual variation when reporting nausea. Delayed nausea was more common among older women while acute nausea was more common among younger women, even if variability occurred in each group. These findings agree with previous studies $[43,117,118]$. These differences may be explained by the fact that the younger women were more often treated with other types of antiemetics than the older women experienced. An interesting result from our study is that the day following CT that the women scored as "the worst day" was also the day they scored highest on CINV. This indicates the impact CINV had on the daily life of these women. The study showed that most women estimated CINV with great variety and some of the women did not follow the pattern from other studies $[58,118]$.

In the second paper (II) the 33 patients included in the first paper were also included. A wide variety in CINV was found with the CT regimen used being FEC which was the first-line treatment at the time of the studies. We found similar results as in paper I in as much as the younger women 
experienced more acute nausea while the older experienced more delayed nausea. Vomiting was only reported by a minority $(16 \%)$ of the patients. An interesting finding in paper II was that we could link the data from the diaries to the different SNPs. Our analysis (48 SNPs in 43 genes) showed an association to three SNPs in three genes indicating a significant risk for nausea. The SNPs and genes associated to CINV were rs2530797 in CCL2, rs2234978 in FAS/CD95 and rs2854344 in RB1/ LPAR6 with those genes having important roles for cellular stability control. One (FAS/CD95) is associated to inflammatory processes. Another (CCL2) mediates apoptosis and the third (RB1/LPAR6) is associated with cell cycle control pathways. Many other genes and SNPs were tested but even those who have showed association with nausea related to opioid use showed no association in our study.

The third paper (III) is about the side effects in the skin after RT in women who were treated for BC. Other studies have indicated an individual genetic variation which could be linked to ARSR and related symptoms after RT $[60,119,120]$. The women in this study reported symptoms related to ARSR (itching, burning and irritation related to irritated skin) twice (during the first and last week of RT). Measurements at the last week of treatment were linked to the results reported and these results were then associated with genetic analyses from blood samples taken before the start of the treatment. There are several studies on different risk factors for ARSR. These risk factors include breast size, Body Mass Index-values, smoking and the modality of RT used [64, 121-127]. There are also some conflicting results, especially concerning smoking and skin type. Even if these previous studies add important knowledge on the treatment- and patient-related risk factors for ARSR, these factors do not explain the individual variations in 
ARSR. We found 2 possible SNPs in 2 out of 28 genes to be associated to ARSR and related symptoms. The association of the symptoms of burning and itching were found in genes XRCC2 SNP rs2040639 and IFNg rs2069750 respectively. According to the skin care protocol at the RT Department, a moisturising cream was recommended during the entire RT period with a corticosteroid cream being recommended only after the onset of ARSR. We observed that the redness continued throughout the treatment even after initiating corticosteroid treatment when the ARSR was already established. The anti-inflammatory effect of steroids is complex with the effect and mode of action when used early in the inflammation process is well documented. However, the mechanism when used late in the inflammatory process is not fully understood [128-130]. This observation implies that more research and confirmation on the effects of corticosteroids for the treatment of ARSR is needed.

In the fourth paper (IV) sleep disturbances were studied with the purpose of describing the extent of the problem among cancer patients undergoing systemic treatment as well as how the HRQoL in patients was affected. There may be many factors influencing sleep disturbances among cancer patients. Co-existing symptoms such as depression, anxiety, pain and/or diarrhoea may impact sleep. Interestingly, some patients that scored disturbed sleep (measured by MOS) responded in the open-ended questions that they slept well. The use of validated instruments to obtain information about sleeping patterns is of importance in order to gain accurate information about the problem studied. We noted that more information about sleep pattern and QoL was obtained from the validated questionnaires MOS [131] and EORTC QLQ C-30 than from the open-ended questions. 
Another important issue is the role of coping strategies for patients suffering disrupted sleep patterns.

The results of the studies in this thesis provide evidence that genetic factors are involved in how different side effects are experienced by each individual. Based on the nursing perspective and on the basis of the results we have obtained, it is of importance to be able to adjust the individual treatment of the people who undergo cancer treatment. The strategies can help the patients to make the disease a part of their life, thus experiencing a better HRQoL. 


\section{Strengths and limitations}

The self-reported data gives power to the results of the four papers with another advantage being that the genetic techniques are well established. The results indicate a possible genetic impact on the development of nausea, both in the acute and the delayed form, post CT. The same conclusion can be drawn regarding $\mathrm{RT}$ patients in relation to ARSR.

From the perspective of data analysis, the strength of the studies is that we, when possible, used different validated instruments to collect data: for observing sleep quality the MOS sleep scale was used and for examining the HRQoL the EORTC QLQ- C30 questionnaire was used. Furthermore, the VAS scale was used in combination with open-ended questions and telephone calls. In addition, a custom-made diary was developed to gather patient-recorded data. The use of those instruments is important to gain knowledge about how the patients themselves experience their health situation and the care provided.

One weakness is the fact that only a selected number of possible SNPs were investigated. Exploring the entire genome would possibly identify other interesting SNPs. Thus, the results must be interpreted with great caution and should be validated in other patient groups.

The populations in our studies were relatively small; a larger study would more accurately determine the association between genetic background and CINV after CT as well as for ARSR after RT. Other weaknesses of the studies are that we used few measurement points, having more measuring points could possibly deliver other results. 
A limitation of paper IV could be that we did not collect details on one of the known risk factors for sleep disturbance; alcohol consumption was not quantitatively reported. This could have impacted the results as high alcohol consumption may affect sleep patterns [132] . However, none of the women reported that they were heavy drinkers. We also relied on self-reported data on smoking status which have been proven to not be completely reliable in other studies [121]. Another limitation was that many patients did not respond to the open-ended questions. With a higher response rate for the study-specific questions the results might have been different.

From a statistical point of view, the methods used are strong and validated [133]. The Svenssons method analyzes changes between baselines and follows up while also describing the size and direction of change, similarities and differences among the groups [114, 116]. 


\section{Conclusions}

\section{Paper I}

The women experienced nausea and some experienced vomiting associated with chemotherapy with the number and severity of these episodes being very individual. The experienced change of well-being was heterogeneous and did not move in any certain direction. This requires an individualized treatment approach to better meet the individual needs of the women studied.

\section{Paper II}

SNPs in the FAS/CD95, RB1/LPAR6 and CCL2 genes were associated with nausea among women treated with adjuvant FEC for BC. SNPs analysis is fast and of low cost and can be done prior to any cancer therapy. The association between individual SNPs and severe side effects from FEC may contribute to a more personalized care of patients with BC.

\section{Paper III}

The possibility of using these specific SNPs in the genes XRCC2 associated to itching and IFNg associated to burning in the clinical situation would be helpful to personalize treatment and self-care advice. The biomarkers are stable and could easily assist to identify patients with an increased risk of ARSR. However further investigations of the validity of those biomarkers in ARSR are needed. 


\section{Paper IV}

Insufficient sleep is a problem for the cancer patients in this study. The perception of sleep showed a heterogeneous pattern. The cancer treatment does not seem to further worsen the perception of sleep disturbances. However, nocturia was more pronounced while living with the disease was less significant at follow up. As disturbed sleep is a problem this should be of concern in the clinical care for the cancer patients and an individualized approach should be used. 


\section{Clinical implications and future research}

\section{Paper I and II}

The studies showed that there are significant individual variations for nausea and vomiting. This applies both to intensity and over time in women treated with CT for BC. This also applies to well-being. Personalized treatments of nausea and vomiting related to chemotherapy based on biomarkers could be a step in a positive direction. SNPs could in the future be some of these biomarkers.

\section{Paper III}

The results could be used to develop individualized care for the side effects from the RT treatment. Future studies could be directed to explore the clinical relevance of blood-based SNPs as the prognostic biomarkers for ARSR.

\section{Paper IV}

Sleep disturbances is a common problem among cancer patients. It would be of importance to alleviate the problem as we know that sleep is something the body needs to recuperate energy as well as being an important component of HRQoL. More research is needed as it is important to produce a robust evidence base to better understand sleeping problems in cancer patients and their possible impact on anti-cancer treatment results. A proper and dynamic intervention or managing program personalized to cancer patients would be helpful in the care of patients with sleep disturbances. 


\section{Future research}

Translational research including nursing perspectives could improve future clinical research. The collaboration between the different disciplines and professions is important. If the results in this thesis are confirmed they could possibly improve and better personalize the treatments of the antiemetics. To validate the findings in the above studies, further investigation is warranted.

At the present, a randomized multicenter clinical trial concerning the biomarkers found as well as CINV is being conducted. The approach is multifactorial with acupressure being tested in a randomized setting. The purpose is to test the clinical value of the biomarkers found in paper II and to find out if a complementary device (acupressure) would add in the management of CINV.

In the future we want to see if we, using individualized treatment based on genetic analysis of the individual patients' blood, can provide an optimal evidence-based treatment against some side effects. This could be done through a large randomized trial where both clinical and preclinical research is equally important. That is, to go from bed to bench and back again. 


\section{Ongoing study on sleep pattern}

In a further study the association of the clinical outcomes to the hormones melatonin and cortisol in urine will be performed. We are testing if the quantity of the hormones in the urine is abnormal and see changes over time. Genetic variations and gene expression in relation to circadian rhythms and thus to the HRQoL will be studied. The possibility of an association between sleeping patterns during and the outcome after the anticancer treatment is interesting and will be investigated. 


\section{Acknowledgements}

To be able to carry out something, you needed support and help from many. You can do a lot yourself, but you can do much more with help of others. Therefore, I would like to thank the following:

Freddi Lewin, thank you for your wisdom and for sharing it with me! You are the first reason why I have undertaken this challenge. Your generosity and friendship are why you are who you are. Thank you for your patience when I insisted on learning something and took a long time until I understood your point, what you explained and what you meant. Many more white hairs have been obtained since we started this adventure.

Nongnit Lewin, thank you for taking your time to participate in my further education. Without you, I would not have done it.

Charlotta Dabrosin, thank you for your support during the training period and for believing in me.

Lena Sharp, thanks for your kindness and your knowledge. Your interpretations have always been so understandable. It is always fun to visit you at RCC and meet you for supervision. You can!!

Lasse Jensen, with you I have learned to pipette and "do the analysis" on the Elisa plates, very instructive! Thank you for your inspiration to continue with our research. You're the best with your zebrafish!

Mats Nilsson, thank you so much for your great help with statistics and for the bi-supervisorship during my education. Thank you for your patience and 
your time, you made this seem easy. Your rings and your red shoes are super cool!

Thank you for all the financial support to Futurum- the Academy for Healthcare. Region Jönköping's county should be proud to have you as a part of the region. Thanks to everyone who works there!

Stiftelsen Fonden för Klinisk Cancerforskning i Jönköping, thank you for the financial support towards our projects. You have made this possible.

To Linköping's University, thank you for making my education a reality. Thank you to the library staff at Ryhov and the printing office for all the help. You are important!

Michael Strandéus, thank you for your support and contribution to my work and for your friendship.

Jeanette Palm and Johanna Svensson, my bosses! Without your support, this would not have been real. Thank you so much for your great help and for your efforts so I could secure time to do the research. Thank you for great support!

Per Nodbrant, the head of the department, thank you for your role in making my studies possible and for your support.

The doctors, for making my work useful and for the support you showed to the work I do.

My dear coworkers in the clinic Maria Walton, Danijela Cuadra, Rose Marie Svensson, Elisabet Norén, Silvia Webers, Valerija Vennstigen, Marie Linder, Sabina Karvo, Sabina Kinander, Eva-Karin Johansson, Stina Bjärkhed, Maria Jackson and Annika Junehed. To everyone from the 
daycare: Madeleine, Gunlög, Linda D, Linda J, Sara, Annie, Gunilla, Anki, Mathilda, Ida and Tobias. To my coworkers at the department of radiotherapy, thank you everyone for great collaboration and for your friendship and for the contribution with data collection. I could not have wished for better help.

Jenny Pettersson, Charlotte Andersson, Margaretha Karlsson, Gabriella Germundsson and Ewa Aspelin thank you for sharing the space with me on the oncogenetic office and for being kind and for the fika.

Bengt-Åke (Benke) Andersson, you have to hurry to take charge in the laboratory so that we can continue our great cooperation. Thank you for your support and collaboration!

Levar Shamoun, you are so good! You are kind and you work hard without finding any problems. Thank you for your essential cooperation!

Ingalill Jönsson thanks for your great support and any possible assistance I needed. I like you a lot, you are the best!

Eva Ulff thanks for your support and kindness.

My dearest friends Anna Songsong, Lizette Karlsson and Yvonne Quirt, you have been with me now for many years and support me in every way. Thank you for being a part of my life and for supporting me.

Arturo Rubio and Eva Ellbrant Rubio, my family's closest friends, thank you for being a part of and supporting us in our lives. Thank you so much for being there!

My parents and siblings, without you I would never be here. Thank you for being there for me! 
Edgardo, my husband, thanks for sharing your life with me. It is not always easy when I worked all the time. Thank you for your support and patience in all ways. Alexander and Gabriella, my beloved children, thank you for being part in what I do. You two are the best thing I have achieved so a dissertation is less valued if it is compared to you. Love you a lot and thank you for your support!

A special thanks to all patients who participated in the studies included in the thesis! And thank you to everyone I did not mention for the help I received and for your support. 


\section{References}

1. Adan, A., et al., Circadian typology: a comprehensive review. Chronobiol Int, 2012. 29(9): p. 1153-75.

2. Ahlberg, A., et al., Clinical outcome following radiotherapy and planned neck dissection in $\mathrm{N}+$ head and neck cancer patients. Acta Otolaryngol, 2008. 128(12): p. 1354-60.

3. de Groot, S., et al., Health-related quality of life and its determinants in patients with metastatic renal cell carcinoma. Qual Life Res, 2017.

4. Campbell, P., et al., Recognizing European cancer nursing: Protocol for a systematic review and meta-analysis of the evidence of effectiveness and value of cancer nursing. J Adv Nurs, 2017. 73(12): p. 3144-3153.

5. Charalambous, A., et al., A scoping review of trials of interventions led or delivered by cancer nurses. Int J Nurs Stud, 2018. 86: p. 3643.

6. Bilgin, S. and S. Gozum, Effect of nursing care given at home on the quality of life of patients with stomach cancer and their family caregivers' nursing care. Eur J Cancer Care (Engl), 2018. 27(2): p. e12567.

7. Suhonen, R., et al., Hospitalised cancer patients' perceptions of individualised nursing care in four European countries. Eur J Cancer Care (Engl), 2018. 27(1).

8. Tuominen, L., et al., Effectiveness of nursing interventions among patients with cancer: An overview of systematic reviews. J Clin Nurs, 2018. 
9. Tomey, M.R.A.A.M., Nursing Theorists and their work. 2010. seveth Edition.

10. Cancerfonden, Cancerfondensrapport 2018. 2018.

11. Clevenger, L., et al., Sleep disturbance, distress, and quality of life in ovarian cancer patients during the first year after diagnosis. Cancer, 2013. 119(17): p. 3234-41.

12. King, C.R., Advances in how clinical nurses can evaluate and improve quality of life for individuals with cancer. Oncol Nurs Forum, 2006. 33(1 Suppl): p. 5-12.

13. Browall, M., et al., Daily assessment of stressful events and coping among post-menopausal women with breast cancer treated with adjuvant chemotherapy. Eur J Cancer Care (Engl), 2009. 18(5): p. 507-16.

14. Tantoy, I.Y., et al., Changes in the Occurrence, Severity, and Distress of Symptoms in Patients With Gastrointestinal Cancers Receiving Chemotherapy. J Pain Symptom Manage, 2018. 55(3): p. 808-834.

15. Hill, N.L., J. Penrod, and P. Milone-Nuzzo, Merging personcentered care with translational research to improve the lives of older adults: creating community-based nursing research networks. J Gerontol Nurs, 2014. 40(10): p. 66-74.

16. De Fazio, P., et al., Hospitalization and other risk factors for depressive and anxious symptoms in oncological and nononcological patients. Psychooncology, 2016.

17. Jordan, K., et al., Neuropharmacology and management of chemotherapy-induced nausea and vomiting in patients with breast cancer. Breast Care (Basel), 2014. 9(4): p. 246-53. 
18. Hesketh, P.J., Management of nausea and vomiting in cancer and cancer treatment. 2005, Canada: Jones and Bartlett Publishers.

19. Pitman, A., et al., Depression and anxiety in patients with cancer. BMJ, 2018. 361: p. k1415.

20. Curran, L., L. Sharpe, and P. Butow, Anxiety in the context of cancer: A systematic review and development of an integrated model. Clin Psychol Rev, 2017. 56: p. 40-54.

21. Mitchell, A.J., et al., Prevalence of depression, anxiety, and adjustment disorder in oncological, haematological, and palliativecare settings: a meta-analysis of 94 interview-based studies. Lancet Oncol, 2011. 12(2): p. 160-74.

22. Salonen, P., et al., Changes in quality of life in patients with breast cancer. J Clin Nurs, 2011. 20(1-2): p. 255-66.

23. Evangelista, A.L. and E.M. Santos, Cluster of symptoms in women with breast cancer treated with curative intent. Support Care Cancer, 2012. 20(7): p. 1499-506.

24. Rojas, K. and A. Stuckey, Breast Cancer Epidemiology and Risk Factors. Clin Obstet Gynecol, 2016. 59(4): p. 651-672.

25. Jones, M.E., et al., Smoking and risk of breast cancer in the Generations Study cohort. Breast Cancer Res, 2017. 19(1): p. 118.

26. Narod, S.A. and L. Salmena, BRCA1 and BRCA2 mutations and breast cancer. Discov Med, 2011. 12(66): p. 445-53.

27. Kotsopoulos, J., et al., Bilateral Oophorectomy and Breast Cancer Risk in BRCA1 and BRCA2 Mutation Carriers. J Natl Cancer Inst, 2017. 109(1).

28. Rousset-Jablonski, C. and A. Gompel, Screening for familial cancer risk: Focus on breast cancer. Maturitas, 2017. 105: p. 69-77. 
29. McDonald, E.S., et al., Clinical Diagnosis and Management of Breast Cancer. J Nucl Med, 2016. 57 Suppl 1: p. 9S-16S.

30. Haque, R., et al., Impact of breast cancer subtypes and treatment on survival: an analysis spanning two decades. Cancer Epidemiol Biomarkers Prev, 2012. 21(10): p. 1848-55.

31. Zdenkowski, N., et al., Supportive care of women with breast cancer: key concerns and practical solutions. Med J Aust, 2016. 205(10): p. 471-475.

32. Stephens, P.A., et al., Identifying the educational needs and concerns of newly diagnosed patients with breast cancer after surgery. Clin J Oncol Nurs, 2008. 12(2): p. 253-8.

33. Burnet, K., et al., Nurse specialists in breast care: a developing role. Nurs Stand, 2004. 18(45): p. 38-42.

34. Del Mastro, L., et al., Fluorouracil and dose-dense chemotherapy in adjuvant treatment of patients with early-stage breast cancer: an open-label, 2 × 2 factorial, randomised phase 3 trial. Lancet, 2015. 385(9980): p. 1863-72.

35. Ahvazi, N.C., S. Hemati, and M. Mohamadianpanah, Effect of increase in duration of aprepitant consumption from 3 to 6 days on the prevention of nausea and vomiting in women receiving combination of anthracycline/cyclophosphamide chemotherapy: A randomized, crossover, clinical trial. Adv Biomed Res, 2015. 4: p. 238.

36. Shih, V., H.S. Wan, and A. Chan, Clinical predictors of chemotherapy-induced nausea and vomiting in breast cancer patients receiving adjuvant doxorubicin and cyclophosphamide. Ann Pharmacother, 2009. 43(3): p. 444-52. 
37. Khasraw, M., R. Bell, and C. Dang, Epirubicin: is it like doxorubicin in breast cancer? A clinical review. Breast, 2012. 21(2): p. 142-9.

38. Moore, M.J., Clinical pharmacokinetics of cyclophosphamide. Clin Pharmacokinet, 1991. 20(3): p. 194-208.

39. de Jonge, M.E., et al., Clinical pharmacokinetics of cyclophosphamide. Clin Pharmacokinet, 2005. 44(11): p. 1135-64.

40. Jordan, V.C., A Retrospective: On Clinical Studies with 5Fluorouracil. Cancer Res, 2016. 76(4): p. 767-8.

41. Early Breast Cancer Trialists' Collaborative, G., et al., Comparisons between different polychemotherapy regimens for early breast cancer: meta-analyses of long-term outcome among 100,000 women in 123 randomised trials. Lancet, 2012. 379(9814): p. 432-44.

42. Navari, R.M. and D. Camp-Sorrell, Chemotherapy-induced nausea and vomiting. 2010, New York: Oxford University Press.

43. Roscoe, J.A., et al., Insight in the prediction of chemotherapyinduced nausea. Support Care Cancer, 2010. 18(7): p. 869-76.

44. Jurgensmeier, J.M., J.P. Eder, and R.S. Herbst, New strategies in personalized medicine for solid tumors: molecular markers and clinical trial designs. Clin Cancer Res, 2014. 20(17): p. 4425-35.

45. Tang, J., et al., DNA methylation and personalized medicine. J Clin Pharm Ther, 2014.

46. Salihah, N., N. Mazlan, and P.L. Lua, Chemotherapy-induced nause and vomiting: exploring patients' subjective experience. $\mathrm{J}$ Multidiscip Healthc, 2016. 9: p. 145-51.

47. Ulff, E., et al., A potent steroid cream is superior to emollients in reducing acute radiation dermatitis in breast cancer patients treated with adjuvant radiotherapy. A randomised study of betamethasone 
versus two moisturizing creams. Radiother Oncol, 2013. 108(2): p. 287-92.

48. Sharp, L., et al., Frequency and severity of skin reactions in patients with breast cancer undergoing adjuvant radiotherapy, the usefulness of two assessment instruments - a pilot study. Eur J Cancer, 2011. 47(18): p. 2665-72.

49. Harper, J.L., et al., Skin toxicity during breast irradiation: pathophysiology and management. South Med J, 2004. 97(10): p. 989-93.

50. Badger, T.A., C.J. Braden, and M.H. Mishel, Depression burden, self-help interventions, and side effect experience in women receiving treatment for breast cancer. Oncol Nurs Forum, 2001. 28(3): p. 567-74.

51. Hilarius, D.L., et al., Chemotherapy-induced nausea and vomiting in daily clinical practice: a community hospital-based study. Support Care Cancer, 2012. 20(1): p. 107-17.

52. Molassiotis, A., et al., Understanding the concept of chemotherapyrelated nausea: the patient experience. Eur J Cancer Care (Engl), 2008. 17(5): p. 444-53.

53. Booth, C.M., et al., Chemotherapy-induced nausea and vomiting in breast cancer patients: a prospective observational study. J Support Oncol, 2007. 5(8): p. 374-80.

54. Richardson, J., et al., Hypnosis for nausea and vomiting in cancer chemotherapy: a systematic review of the research evidence. Eur $\mathbf{J}$ Cancer Care (Engl), 2007. 16(5): p. 402-12. 
55. Fredrikson, M., et al., Delayed chemotherapy-induced nausea is augmented by high levels of endogenous noradrenaline. Br J Cancer, 1994. 70(4): p. 642-5.

56. Navari, R.M. and M. Aapro, Antiemetic Prophylaxis for Chemotherapy-Induced Nausea and Vomiting. N Engl J Med, 2016. 374(14): p. 1356-67.

57. Hesketh, P.J., et al., Antiemetics: American Society of Clinical Oncology Focused Guideline Update. J Clin Oncol, 2016. 34(4): p. 381-6.

58. Oliva, D., et al., Single nucleotide polymorphisms might influence chemotherapy induced nausea in women with breast cancer. Clinical and Translational Radiation Oncology, 2017. 2: p. 1-6.

59. Clark-Snow, R., M.L. Affronti, and C.N. Rittenberg, Chemotherapyinduced nausea and vomiting (CINV) and adherence to antiemetic guidelines: results of a survey of oncology nurses. Support Care Cancer, 2018. 26(2): p. 557-564.

60. Song, Y.Z., et al., Association between Single Nucleotide Polymorphisms in XRCC3 and Radiation-Induced Adverse Effects on Normal Tissue: A Meta-Analysis. PLoS One, 2015. 10(6): p. e0130388.

61. Mladenov, E., et al., DNA double-strand break repair as determinant of cellular radiosensitivity to killing and target in radiation therapy. Front Oncol, 2013. 3: p. 113.

62. Andreassen, C.N., J. Alsner, and J. Overgaard, Does variability in normal tissue reactions after radiotherapy have a genetic basis-where and how to look for it? Radiother Oncol, 2002. 64(2): p. 13140. 
63. Barnett, G.C., et al., Incorporating Genetic Biomarkers into Predictive Models of Normal Tissue Toxicity. Clin Oncol (R Coll Radiol), 2015. 27(10): p. 579-87.

64. Ulff, E., et al., Prophylactic treatment with a potent corticosteroid cream ameliorates radiodermatitis, independent of radiation schedule: A randomized double blinded study. Radiother Oncol, 2016.

65. Plataniotis, G., Hypofractionated radiotherapy in the treatment of early breast cancer. World J Radiol, 2010. 2(6): p. 197-202.

66. Whelan, T.J., et al., Long-term results of hypofractionated radiation therapy for breast cancer. N Engl J Med, 2010. 362(6): p. 513-20.

67. Andreassen, C.N. and J. Alsner, Genetic variants and normal tissue toxicity after radiotherapy: a systematic review. Radiother Oncol, 2009. 92(3): p. 299-309.

68. De Langhe, S., et al., Factors modifying the risk for developing acute skin toxicity after whole-breast intensity modulated radiotherapy. BMC Cancer, 2014. 14: p. 711.

69. Cox, J.D., J. Stetz, and T.F. Pajak, Toxicity criteria of the Radiation Therapy Oncology Group (RTOG) and the European Organization for Research and Treatment of Cancer (EORTC). Int J Radiat Oncol Biol Phys, 1995. 31(5): p. 1341-6.

70. Sharp, L., et al., No differences between Calendula cream and aqueous cream in the prevention of acute radiation skin reactions-results from a randomised blinded trial. Eur J Oncol Nurs, 2013. 17(4): p. 429-35.

71. Russell, N.S., E. van Werkhoven, and S.B. Schagen, Quantification of patient-reported outcome measures of radiation-induced skin 
reactions for use in clinical trial design. Support Care Cancer, 2017. 25(1): p. 67-74.

72. Mormont, M.C., et al., Marked 24-h rest/activity rhythms are associated with better quality of life, better response, and longer survival in patients with metastatic colorectal cancer and good performance status. Clin Cancer Res, 2000. 6(8): p. 3038-45.

73. Pavlova, M., Circadian Rhythm Sleep-Wake Disorders. Continuum (Minneap Minn), 2017. 23(4, Sleep Neurology): p. 1051-1063.

74. Palesh, O., et al., Relationship between subjective and actigraphymeasured sleep in 237 patients with metastatic colorectal cancer. Qual Life Res, 2017.

75. Chen, D., Z. Yin, and B. Fang, Measurements and status of sleep quality in patients with cancers. Support Care Cancer, 2018. 26(2): p. 405-414.

76. Dumont, M. and J. Paquet, Progressive decrease of melatonin production over consecutive days of simulated night work. Chronobiol Int, 2014. 31(10): p. 1231-8.

77. Sephton, S.E., et al., Diurnal cortisol rhythm as a predictor of breast cancer survival. J Natl Cancer Inst, 2000. 92(12): p. 994-1000.

78. Haack, M., E. Sanchez, and J.M. Mullington, Elevated inflammatory markers in response to prolonged sleep restriction are associated with increased pain experience in healthy volunteers. Sleep, 2007. 30(9): p. 1145-52.

79. Jensen, L.D., et al., Opposing effects of circadian clock genes bmall and period 2 in regulation of VEGF-dependent angiogenesis in developing zebrafish. Cell Rep, 2012. 2(2): p. 231-41. 
80. Klein, J.T., Interdisciplinarity and Transdisciplinarity: Keyword Meanings for Collaboration Science and Translational Medicine. Journal of Translational Medicine \& Epidemiology, 2014. 2(2): 1024: p. 1-7.

81. https://sv.wikipedia.org/wiki/translationell_forskning, Translationell forskning 2019.

82. Woods, N.F. and D.L. Magyary, Translational research: why nursing's interdisciplinary collaboration is essential. Res Theory Nurs Pract, 2010. 24(1): p. 9-24.

83. Lin, C.C., Why does translational research matter to cancer nursing researchers? Cancer Nurs, 2013. 36(4): p. 337-8.

84. Smith, K.W., N.E. Avis, and S.F. Assmann, Distinguishing between quality of life and health status in quality of life research: a metaanalysis. Qual Life Res, 1999. 8(5): p. 447-59.

85. Siri Næss, T.M., John EriksenSiri Næss, Torbjørn Moum, John Eriksen, Livskvalitet: forskning om det gode liv. 2011.

86. Nordenfelt, L., The concepts of health and illness revisited. Med Health Care Philos, 2007. 10(1): p. 5-10.

87. General guidelines for the preclinical toxicology of new cytotoxic anticancer agents in Europe. Joint Steering Committee of the European Organization for Research and Treatment of Cancer (EORTC) and the Cancer Research Campaign (CRC). Eur J Cancer, 1990. 26(3): p. 411-4.

88. Sprangers, M.A., et al., The European Organization for Research and Treatment of Cancer. Approach to quality of life assessment: guidelines for developing questionnaire modules. EORTC Study Group on Quality of Life. Qual Life Res, 1993. 2(4): p. 287-95. 
89. Burtles, S.S., et al., Revisions of general guidelines for the preclinical toxicology of new cytotoxic anticancer agents in Europe. The Cancer Research Campaign (CRC) Phase I/II Clinical Trials Committee and the European Organization for Research and Treatment of Cancer (EORTC) New Drug Development Office. Eur J Cancer, 1995. 31A(3): p. 408-10.

90. Maltoni, M., et al., Prognostic factors in advanced cancer patients: evidence-based clinical recommendations--a study by the Steering Committee of the European Association for Palliative Care. J Clin Oncol, 2005. 23(25): p. 6240-8.

91. Yates, J.W., B. Chalmer, and F.P. McKegney, Evaluation of patients with advanced cancer using the Karnofsky performance status. Cancer, 1980. 45(8): p. 2220-4.

92. Evans, C. and M. McCarthy, Prognostic uncertainty in terminal care: can the Karnofsky index help? Lancet, 1985. 1(8439): p. 12046.

93. Shen, M., et al., Polymorphisms of the DNA repair genes XRCC1, $X R C C 3, X P D$, interaction with environmental exposures, and bladder cancer risk in a case-control study in northern Italy. Cancer Epidemiol Biomarkers Prev, 2003. 12(11 Pt 1): p. 1234-40.

94. Wang, L., et al., Increased risk of prostate cancer associated with AA genotype of cyclin D1 gene A870G polymorphism. Int J Cancer, 2003. 103(1): p. 116-20.

95. Oliva, D., et al., Individual Genetic Variation Might Predict Acute Skin Reactions in Women Undergoing Adjuvant Breast Cancer Radiotherapy. Anticancer Res, 2018. 38(12): p. 6763-6770. 
96. Akimzhanov, A.M., et al., T-cell receptor complex is essential for Fas signal transduction. Proc Natl Acad Sci U S A, 2010. 107(34): p. 15105-10.

97. Alderson, M.R., et al., Fas transduces activation signals in normal human T lymphocytes. J Exp Med, 1993. 178(6): p. 2231-5.

98. Malleter, M., et al., CD95L cell surface cleavage triggers a prometastatic signaling pathway in triple-negative breast cancer. Cancer Res, 2013. 73(22): p. 6711-21.

99. Mateu, E., et al., Genetics of retinoblastoma: a study. Cancer Genet Cytogenet, 1997. 95(1): p. 40-50.

100. Van Orsouw, N.J., et al., Mutational scanning of large genes by extensive PCR multiplexing and two-dimensional electrophoresis: application to the RB1 gene. Hum Mol Genet, 1996. 5(6): p. 755-61.

101. Song, H., et al., Common variants in RB1 gene and risk of invasive ovarian cancer. Cancer Res, 2006. 66(20): p. 10220-6.

102. Tsuyada, A., et al., CCL2 mediates cross-talk between cancer cells and stromal fibroblasts that regulates breast cancer stem cells. Cancer Res, 2012. 72(11): p. 2768-79.

103. Li, M., et al., A role for CCL2 in both tumor progression and immunosurveillance. Oncoimmunology, 2013. 2(7): p. e25474.

104. Kitamura, T., et al., CCL2-induced chemokine cascade promotes breast cancer metastasis by enhancing retention of metastasisassociated macrophages. J Exp Med, 2015. 212(7): p. 1043-59.

105. Gonsky, R., et al., IFNG rs1861494 polymorphism is associated with IBD disease severity and functional changes in both IFNG methylation and protein secretion. Inflamm Bowel Dis, 2014. 20(10): p. 1794-801. 
106. Gao, L., et al., Targeted deep sequencing identifies rare loss-offunction variants in IFNGR1 for risk of atopic dermatitis complicated by eczema herpeticum. J Allergy Clin Immunol, 2015. 136(6): p. 1591-600.

107. Silva, S.N., et al., Breast cancer risk and common single nucleotide polymorphisms in homologous recombination DNA repair pathway genes XRCC2, XRCC3, NBS1 and RAD51. Cancer Epidemiol, 2010. 34(1): p. 85-92.

108. Qin, C.-J., et al., XRCC2 as a predictive biomarker for radioresistance in locally advanced rectal cancer patients undergoing preoperative radiotherapy. Oncotarget, 2015. 6(31): $\mathrm{p}$. 32193.

109. Allen, R.P., et al., Psychometric evaluation and tests of validity of the Medical Outcomes Study 12-item Sleep Scale (MOS sleep). Sleep Med, 2009. 10(5): p. 531-9.

110. Michelson, H., et al., Health-related quality of life measured by the EORTC QLQ-C30--reference values from a large sample of Swedish population. Acta Oncol, 2000. 39(4): p. 477-84.

111. Mayo, O., A century of Hardy-Weinberg equilibrium. Twin Res Hum Genet, 2008. 11(3): p. 249-56.

112. Orwelius, L., et al., The Swedish RAND-36 Health Survey reliability and responsiveness assessed in patient populations using Svensson's method for paired ordinal data. J Patient Rep Outcomes, 2017. 2(1): p. 4.

113. Wikstrom, L., et al., Patients' self-reported nausea: Validation of the Numerical Rating Scale and of a daily summary of repeated 
Numerical Rating Scale scores. J Clin Nurs, 2019. 28(5-6): p. 959968.

114. Avdic, A. and E. Svensson. Svenssons method (Version 1.1). Örebro. Interactive software supporting Svenssons method. 2010 2013-04-19]; Available from: http://www.oru.se/hh/ElisabethSvensson/Svenssons_metod.

115. Svensson, E., Vad är behandlingseffekt om patienten blev bättre men ingen vet hur mycket? Lakartidningen, 2005. 43: p. 3138-45.

116. Svensson, E., Statistisk metod för parade ordinaldata [What is the therapeutic effect if the patient gets better, but no one knows how much better? Statistical method for paired ordinal data]. Lakartidningen, 2007. 104: p. 596-601.

117. Dibble, S.L., et al., Acupressure for chemotherapy-induced nausea and vomiting: a randomized clinical trial. Oncol Nurs Forum, 2007. 34(4): p. 813-20.

118. Oliva, D., et al., Variations in self-reported nausea, vomiting, and well-being during the first 10 days postchemotherapy in women with breast cancer. Clin J Oncol Nurs, 2014. 18(2): p. E32-6.

119. Ho, A.Y., et al., Genetic predictors of adverse radiotherapy effects: the Gene-PARE project. Int J Radiat Oncol Biol Phys, 2006. 65(3): p. 646-55.

120. Azria, D., et al., Single nucleotide polymorphisms, apoptosis, and the development of severe late adverse effects after radiotherapy. Clin Cancer Res, 2008. 14(19): p. 6284-8.

121. Sharp, L., et al., Smoking as an independent risk factor for severe skin reactions due to adjuvant radiotherapy for breast cancer. Breast, 2013. 22(5): p. 634-8. 
122. Fitzgerald, T.J., et al., Radiation therapy toxicity to the skin. Dermatol Clin, 2008. 26(1): p. 161-72, ix.

123. Porock, D., et al., Predicting the severity of radiation skin reactions in women with breast cancer. Oncol Nurs Forum, 1998. 25(6): p. 1019-29.

124. Chan, R.J., et al., Prevention and treatment of acute radiationinduced skin reactions: a systematic review and meta-analysis of randomized controlled trials. BMC Cancer, 2014. 14: p. 53.

125. Wells, M., et al., Does aqueous or sucralfate cream affect the severity of erythematous radiation skin reactions? A randomised controlled trial. Radiother Oncol, 2004. 73(2): p. 153-62.

126. Twardella, D., et al., Personal characteristics, therapy modalities and individual DNA repair capacity as predictive factors of acute skin toxicity in an unselected cohort of breast cancer patients receiving radiotherapy. Radiother Oncol, 2003. 69(2): p. 145-53.

127. Pignol, J.P., et al., A multicenter randomized trial of breast intensitymodulated radiation therapy to reduce acute radiation dermatitis. $\mathbf{J}$ Clin Oncol, 2008. 26(13): p. 2085-92.

128. Coutinho, A.E. and K.E. Chapman, The anti-inflammatory and immunosuppressive effects of glucocorticoids, recent developments and mechanistic insights. Mol Cell Endocrinol, 2011. 335(1): p. 213.

129. Miller, R.C., et al., Mometasone furoate effect on acute skin toxicity in breast cancer patients receiving radiotherapy: a phase III doubleblind, randomized trial from the North Central Cancer Treatment Group N06C4. Int J Radiat Oncol Biol Phys, 2011. 79(5): p. 1460-6. 
130. Bostrom, A., et al., Potent corticosteroid cream (mometasone furoate) significantly reduces acute radiation dermatitis: results from a double-blind, randomized study. Radiother Oncol, 2001. 59(3): p. 257-65.

131. Mosli, M.H., et al., Toward a personalized medicine approach to the management of inflammatory bowel disease. Am J Gastroenterol, 2014. 109(7): p. 994-1004.

132. Colrain, I.M., C.L. Nicholas, and F.C. Baker, Alcohol and the sleeping brain. Handb Clin Neurol, 2014. 125: p. 415-31.

133. Bradley, M.T. and A. Brand, Accuracy when inferential statistics are used as measurement tools. BMC Res Notes, 2016. 9: p. 241. 
Appendix 1

Diary after chemotherapy, during 10 days

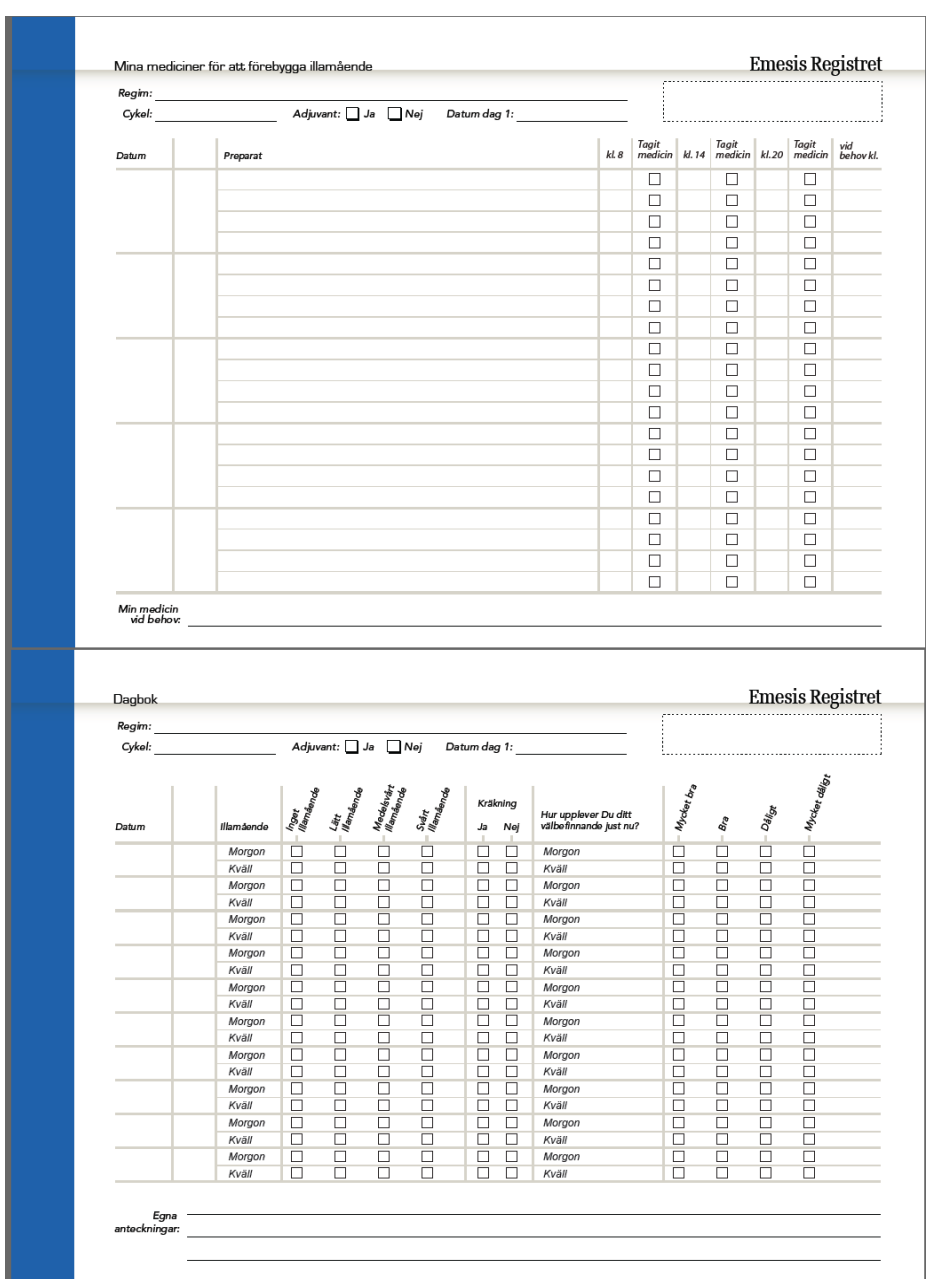

https://vardgivarwebb.regionostergotland.se/pages/103866/Dagbok Emesisregis ter.pdf 


\section{Appendix 2}

\section{VAS scale used in connection with chemotherapy}

Mätning av illamående med hjälp av VAS-skala (Visuell Analog Skala)

0 - 10, där 0 är ingen illamående och 10 är värsta tänkbara illamående.

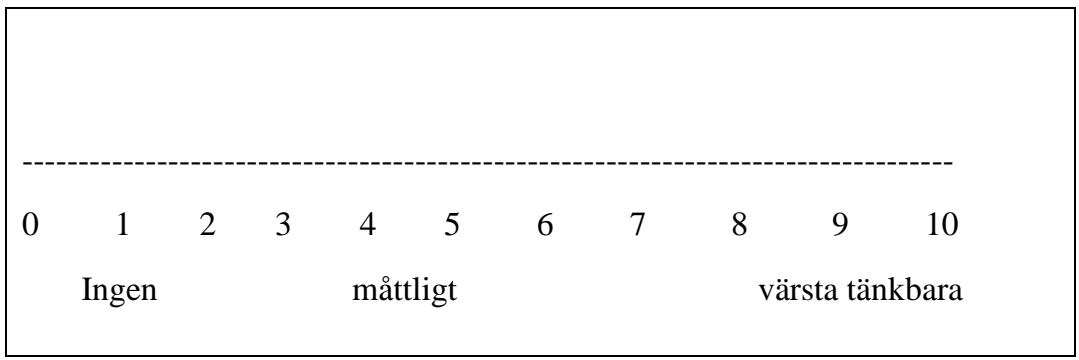

Utifrån den här skalan kommer jag vid telefonuppföljning att fråga dig hur svårt illamående du upplev. Det är din egen skattning och därför viktigt att den kontrolleras.

- Du kommer att bli kontaktad via telefon efter behandlingsstart, cirka tio dagar efter.

- Om du ska få 6 behandlingar, kommer jag att kontakta dig efter behandling $\mathrm{nr} 1$, behandling $\mathrm{nr} 3$ och behandling $\mathrm{nr} 6$.

- Om du ska få 3 behandlingar, kommer jag att kontakta dig efter alla behandlingar 
Appendix 3

\section{Phone follow-up 10 days after chemotherapy}

\section{Kod:}

Behandling nr.

\section{Datum}

\section{Dag 10}

\section{Telefonuppföljning}

Frågor som ställs vid telefonuppföljning behandlingstillfälle 1, 3 och 6; alt behandlingstillfälle $1,2,3$ dag 10

Har du mått illa $\quad$ ja nej

Om du har mått illa, kan du uppskatta intensiteten med hjälp av VAS skalan, som du blev undervisad, i en skala från 1 till 10, där 1 är ingenting och 10 är värsta tänkbara.

Har du kräks $\quad$ ja nej

Om ja. Hur många gånger

Vilken dag var värst? $1,2,3,4,5,6,7,8,9,10$ 
Appendix 4

\section{VAS -skin reactions measurement}

Patientkod.

\section{Hur känns huden på det strålade bröstet?}

$0=$ Inga besvär avseende klåda, irritation, sveda

$10=$ Värsta tänkbara besvär avseende klåda, irritation sveda

Kryssa på den punkt på linjen som bäst motsvarar dina besvär

Klåda

0

Sveda

0

Irritation

0

KONTROLL 1+ 2

\begin{tabular}{|c|c|c|c|}
\hline RTOG & JA & NEJ & \\
\hline Grad 0 & & & Ingen hudreaktion. \\
\hline Grad 1 & & & $\begin{array}{l}\text { Lätt hudrodnad lindrig värmeökning och } \\
\text { Stramande känsla i huden }\end{array}$ \\
\hline Grad 2 & & & Måttlig till kraftig hudrodnad. Torr fjällning. \\
\hline Grad 3 & & & $\begin{array}{l}\text { Kraftig hudrodnad med partier av fuktig } \\
\text { Hudlossning. }\end{array}$ \\
\hline Grad 4 & & & Ulcererande, blödande hud och nekros \\
\hline \multicolumn{4}{|c|}{ RTOG $=$ the Radiation Therapy Oncology Group } \\
\hline
\end{tabular}




\section{Appendix 5}

\section{Din Sömn}

För var och en av nedanstående frågor ska Du markera ett $\bigotimes$ in den ruta som bäst beskriver Ditt svar.

1. Hur lång tid tog det Dig vanligen att somna under de senaste 4 veckorna?

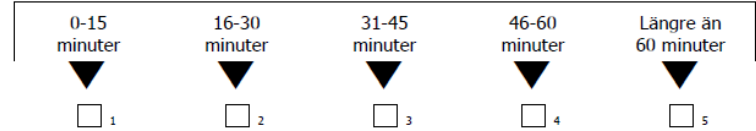

2. Hur många timmar per natt har Du i genomsnitt sovit under de senaste 4 veckorna?

Skriv antal timmar per natt:

3. Hur ofta under de senaste 4 veckorna har Du...

känt att Du haft en orolig sömn

(vänt och vridit på Dig, känt

Dig spänd, pratat i sömnen etc)?

\begin{tabular}{|lccc|}
\hline Hela & Största delen & En del & Lite \\
tiden & av tiden & av tiden & av tiden \\
av tiden
\end{tabular}

fått tillräckligt med sömn för att

känna Dig utvilad när Du vaknat

på morgonen?
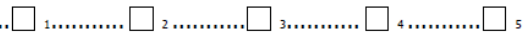

c vaknat andfådd eller med huvudvärk?

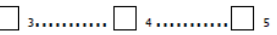

d känt Dig dåsig eller sömnig

under dagen?

e haft svårigheter att somna?

Translation Copyright (c) 1995 2002, 2010 QualityMetric Incorporated. All rights reserved. (Sweden (Swedish) MOS 12-Item Sleep Scale-Revised) 
Hur ofta under de senaste 4 veckorna har Du...

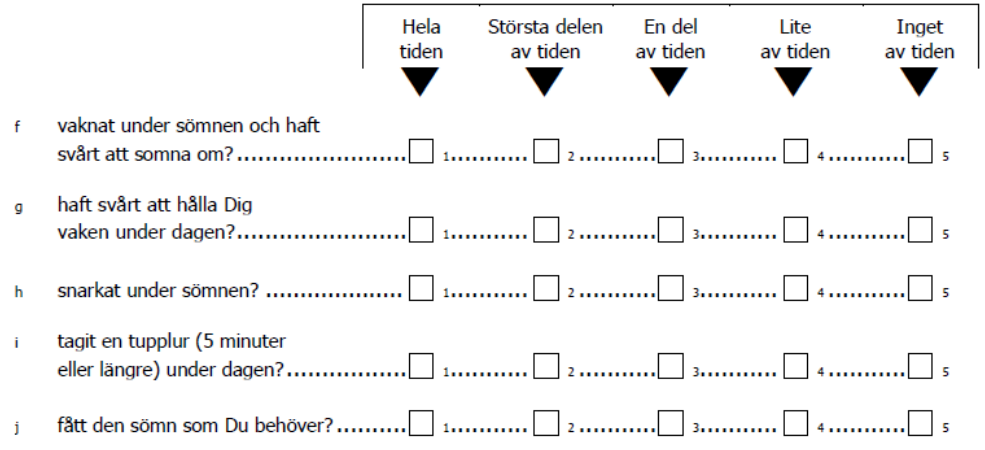

Beskriv hur du upplever kvaliteten av din

sömn:

Vad du tror kan vara orsaken till eventuella

sömnproblem:

Beskriv ditt sömnmönster:

Sover du mest på natten.

mest på dagen

På natten några dagar och på dagen några dagar i veckan

eller båda på dagen och på

natten.

Datum:

Translation Copyright (C) 1995 2002, 2010 QualityMetric Incorporated. All rights reserved. (Sweden (Swedish) MOS 12-Item Sleep Scale-Revised) 


\section{Appendix 6}

SWEDISH

EORTC QLQ-C30 (version 3)

$V_{1}$ är intresserade av några saker som har med dig och din hälsa att göra. Besvara alla frågor genom att sätta en ring runt den siffra som stämmer bäst in på dig. Det finns inga svar som är "rätt" eller "fel". Den information du lämnar kommer att hållas strikt konfidentiell.

Fyll i dina initialer:

När är du född (Dag, Månad, År):

Dagens datum (Dag, Månad, År):



1. Har du svårt att göra ansträngande saker, som att bära en tung kasse eller väska?

2. Har du svårt att ta en lång promenad?

3. Har du svårt att ta en kort promenad utomhus?

4. Måste du sitta eller ligga på dagarna?

5. Behōver du hjälp med att äta, klä dig, tvätta dig eller gå på toaletten?

\begin{tabular}{|c|c|c|c|}
\hline $\begin{array}{l}\text { Inte } \\
\text { alls }\end{array}$ & Lite & $\begin{array}{c}\text { En hel } \\
\text { del }\end{array}$ & Mycket \\
\hline 1 & 2 & 3 & 4 \\
\hline 1 & 2 & 3 & 4 \\
\hline 1 & 2 & 3 & 4 \\
\hline 1 & 2 & 3 & 4 \\
\hline 1 & 2 & 3 & 4 \\
\hline $\begin{array}{l}\text { Inte } \\
\text { alls }\end{array}$ & Lite & $\begin{array}{c}\text { En hel } \\
\text { del }\end{array}$ & Mycket \\
\hline 1 & 2 & 3 & 4 \\
\hline 1 & 2 & 3 & 4 \\
\hline 1 & 2 & 3 & 4 \\
\hline 1 & 2 & 3 & 4 \\
\hline 1 & 2 & 3 & 4 \\
\hline 1 & 2 & 3 & 4 \\
\hline 1 & 2 & 3 & 4 \\
\hline 1 & 2 & 3 & 4 \\
\hline 1 & 2 & 3 & 4 \\
\hline 1 & 2 & 3 & 4 \\
\hline 1 & 2 & 3 & 4 \\
\hline
\end{tabular}

Fortsätt på nästa sida 
Under veckan som gått:

17. Har du haft diarré?

18. Har du varit trōtt?

19. Har dina dagliga aktiviteter påverkats av smärta?

20. Har du haft svårt att koncentrera dig på saker som att läsa en tidning eller titta på TV?

21. Har du känt dig spänd?

22. Har du oroat dig?

23. Har du känt dig irriterad?

24. Har du känt dig nedstämd?

25. Har du haft svårt att komma ihåg saker?

26. Har ditt fysiska tillstånd eller den medicinska behandlingen stört ditt familjeliv?

27. Har ditt fysiska tillstånd eller den medicinska behandlingen stört dina sociala aktiviteter?

28. Har ditt fysiska tillstånd eller den medicinska behandlingen gjort att du fătt ekonomiska svårigheter?

$\begin{array}{cccc}\begin{array}{c}\text { Inte } \\ \text { alls }\end{array} & \text { Lite } & \begin{array}{c}\text { En hel } \\ \text { del }\end{array} & \text { Mycket } \\ 1 & 2 & 3 & 4 \\ 1 & 2 & 3 & 4 \\ 1 & 2 & 3 & 4 \\ \text { 1 } & 2 & 3 & 4 \\ 1 & 2 & 3 & 4 \\ 1 & 2 & 3 & 4 \\ 1 & 2 & 3 & 4 \\ 1 & 2 & 3 & 4 \\ 1 & 2 & 3 & 4 \\ 1 & 2 & 3 & 4 \\ 1 & 2 & 3 & 4 \\ 1 & 2 & 3 & 4\end{array}$

Sätt en ring runt den siffra mellan 1 och 7 som stämmer bäst in på dig för följande frågor:

29. Hur skalle du vilja beskriva din hälsa totalt sett under den vecka som gått?

$\begin{array}{ccccccc}1 & 2 & 3 & 4 & 5 & 6 & 7 \\ \text { Mycket dålig } & & & & & & \text { Utmärkt }\end{array}$

30. Hur skulle du vilja beskriva din totala livskvalitet under den vecka som gått?

$\begin{array}{ccccccc}1 & 2 & 3 & 4 & 5 & 6 & 7 \\ \text { Uâlig } & & & & & & \\ \text { Utmärkt }\end{array}$

- QLQ-C30 Copyright 1995 EORTC Qunlity of Life Group. Alla rättigheter reservernde. Version 3.0.

If you want to use the measure, contact the Quality of life Department at https://qol.eortc.org for the permission 


\section{FACULTY OF MEDICINE AND HEALTH SCIENCES}

Linköping University Medical Dissertation No. 1716, 2019

Department of Clinical and Experimental Medicine

Linköping University

SE-581 83 Linköping, Sweden

www.liu.se 